\title{
La imagen de Santiago del espaldarazo de las Huelgas de Burgos. Escenarios históricos (e historiográficos) de un santo vestidero*
}

\author{
The image of Santiago del Espaldarazo from the monastery of \\ Las Huelgas in Burgos. Historic (and historiographic) scenarios for a \\ "santo vestidero" \\ Eduardo CARRERO SANTAMARÍA \\ Universitat Autònoma de Barcelona \\ ORCID: http://orcid.org/0000-0002-4040-1525 / Eduardo.Carrero@uab.cat \\ DOI: http://dx.doi.org/10.18002/da.v0i18.5906
}

Recibido: 15-IV-2019

Aceptado: 20-VII-2019

RESUMEN: En el monasterio cisterciense de Las Huelgas de Burgos se conserva una imagen sedente y articulada de un hombre barbado, que porta una espada en ristre en su mano derecha. Sus orígenes se han basado en la tradición que la consideraba un intermediario de madera entre la divinidad y el rey, a través de su identificación con el Apóstol Santiago. De este modo, era supuestamente utilizada en el ceremonial de toma de armas de los reyes de Castilla, para dar la pescozada al monarca. Otra hipótesis es la que considera la imagen instrumento de una tradición moderna, basada en la restauración que demostró cómo en realidad se trata de una imagen de la Virgen posiblemente del siglo XIII, alterada en fechas modernas para transformarla en la figura actual. En este artículo se argumenta cómo la imagen, efectivamente, sufrió una transformación moderna y su estatus tradicional debe ser reconsiderado en otras direcciones interpretativas.

Palabras clave: Huelgas; Burgos; Compostela; Santiago del Espaldarazo; Liturgia; Monarquía.

ABSTRACT: In the Cistercian monastery of Las Huelgas de Burgos, a seated and articulated image of a bearded man holding a sword in his right hand is preserved. Its origins have been based on the tradition that considered it a wooden intermediary between the deity and the king, as an image of Saint James. In this way, it was supposedly used during the knighting liturgy for the kings of Castile. Another hypothesis considers the image as an instrument of a modern tradition, based on the restoration that showed how it was actually an image of the Virgin (a thirteenth century one), altered in modern dates to transform it into the current figure. This article argues how the image, in fact, underwent a modern transformation and its traditional interpretation must be reconsidered in other interpretative directions.

Keywords: Huelgas; Burgos; Compostela; Santiago del Espaldarazo; Liturgy; Monarchy.

Una imagen medieval articulada es un campo abonado para convertirse en bastidor de poesías, novelas y, entre sus líneas, imaginar conjuras históricas. Es el caso del conocido como Santiago del Espaldarazo, conservado en el monasterio de Santa María la Real de las Huelgas, en Burgos (Fig. 1). Se trata de una pieza difícil. Una tradición bien arraigada la hacía la intermediaria divina que investía como caballero al rey de

* A la memoria de Francisco Peralta, maestro titiritero. 


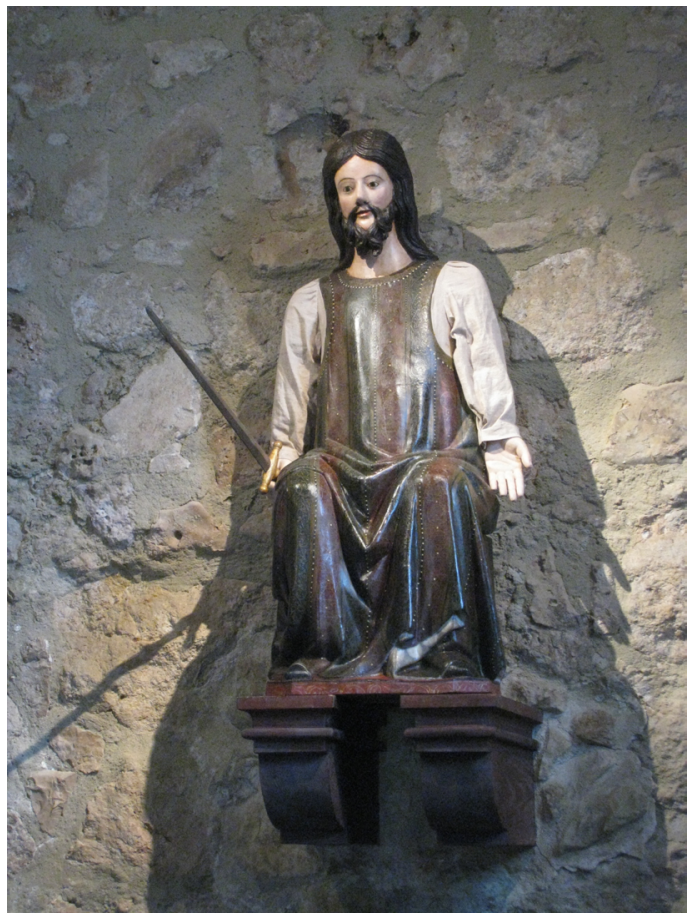

- Fig. 1. Imagen de Santiago del Espaldarazo en la capilla de Santiago. Monasterio de Santa María la Real de Las Huelgas de Burgos. Foto del autor.

Castilla, evitando así cualquier intervención humana, ya fuera civil, ya religiosa. $\mathrm{Y}$ como suele ocurrir, la tradición se convirtió en realidad. Carente de cualquier referencia documental publicada anterior al siglo XVII, la historiografía decidió identificarla en una frase de la crónica de Alfonso XI, cuando el joven rey fue a armarse caballero a la catedral de Santiago de Compostela y, como veremos más adelante, el propio Apóstol le dio la pescozada reglamentaria.

Pero esta no fue la única opinión. Ha habido otras voces en desacuerdo con su origen, sobre todo a partir de la publicación de un pequeño informe de restauración revelando que se trataba de una contrahechura escultórica de una talla de la Virgen, transformada en ruda imagen de Santiago el Mayor ${ }^{1}$. Se indicó lo difícil que resultaba considerar real la historia de la figura aso-

\footnotetext{
${ }^{1}$ Francisco Torrón Durán, “Imagen de Santiago del Espaldarazo de las Huelgas de Burgos", Abrente. Boletín de la Real Academia Gallega de Bellas Artes de Nuestra Señora del Rosario, 38-39 (2006-2007), 73-74.
}

ciada a un rito regio, habida cuenta de la novedad aportada por los restauradores. Lo cierto es que parte de la comunidad científica no aceptó el nuevo estatus de la figura que, de armar caballero a un rey, pasaba a convertirse en un moderno santo vestidero ${ }^{2}$. Tan rápida respuesta en defensa de su papel en el ceremonial regio se basó, por una parte, en la conservación de la tradición pura y dura mientras, por otra, se acogía al criterio de autoridad de otro historiador. Se trata de Peter Linehan, que había establecido una hermosa paráfrasis de la teoría de estado de la monarquía castellana y su "autoconcedida" designación por voluntad divina. Esta quedaba refrendada a través de la imagen del Apóstol en Las Huelgas de Burgos, intermediaria entre Dios y la monarquía, a la vez que bonita nota de color en una presunta teoría política ${ }^{3}$. La hipótesis no era nueva. De hecho, desarrollaba y perfilaba lo que desde hacía tiempo habían propuesto otros autores sobre el interesante reinado de Alfonso XI y sus implicaciones ideológicas ${ }^{4}$. Pero si el in-

\footnotetext{
${ }^{2}$ María José Martínez Martínez, “Las imágenes articuladas en las celebraciones áulicas: la escultura de Santiago del Espaldarazo de las Huelgas de Burgos", Codex aquilarensis, 30 (2014), 259-272; Rosa María Rodríguez Porto, "Mística regia y ambiciones compostelanas. La catedral de Santiago como espacio ceremonial para las monarquías castellana y portuguesa (1319-1332)", Codex aquilarensis, 30 (2014), 133-158 y "Knighted by the Apostle Himself. Political Fabrication and Chivalric Artefact in Compostela, 1332", en The Agency of Things in Medieval and Early Modern Art. Materials, Power and Manipulation, ed. por Grazyna Jurkowlaniec, Ika Matyjaszkiewicz y Zuzanna Sarnecka (Nueva York-Abingdon: Routledge, 2018), 51-60.

${ }^{3}$ La propuesta no ha variado desde 1987 hasta hoy: Peter Linehan, "Ideología y liturgia en el reinado de Alfonso XI de Castilla", en Génesis medieval del estado moderno. Castilla y Navarra (1250-1370) (Valladolid: Ámbito, 1987), 229-244; "The mechanics of monarchy: Knighting Castile's king. 1332", History Today, 43 (1993), 26-32; "Alfonso XI of Castile and the arm of Santiago (with a note on the Pope's foot)", en Miscellanea Domenico Maffei dicata. Historia Jus Studium, ed. por Antonio García García y Peter Weimar (Goldbach: Keip, 1995), IV, 121-146 $\mathrm{y}$ At the Edge of Reformation. Iberia before the Black Death (Oxford: Oxford University Press, 2019), 70-71.
}

${ }^{4}$ Así lo hicieron Bonifacio Palacios Martín, "Los símbolos de la soberanía en la Edad Media española. 
vestigador inglés había tomado por cierto lo mismo que los restantes estudiosos del ceremonial castellano, lo hizo obviando toda una tradición historiográfica que venía de largo y que se cuestionaba la realidad de la imagen y su participación en el ritual regio.

\section{SEGÚN LA TRADICIÓN... UNA HIS- TORIOGRAFÍA DIVERSA}

En el siglo XVII, el cronista Alonso Núñez de Castro narraba la coronación de Enrique I de Castilla de la siguiente forma: “El monasterio de las Huelgas tiene recibido que [Enrique I] fue coronado en dicho monasterio y que, en memoria de esto, conserua una imagen del apóstol Santiago, Patrón de España, la qual con artificio juega los braços; y añaden (según la tradición) que la misma imagen le puso el cetro en las manos y la corona en la cabeça. No doy más autoridad a esta tradición que la de la voz común: si quisieran dezir con ella que la Corona del Rey don Enrique lo pareció de tramoya, pues era Enrique el rey y los de Lara triunfauan contra su corona, tuuiera la tradición más

El símbolo de la espada", en VII Centenario del infante don Fernando de la Cerda, 1275-1975) (Madrid: Instituto de Estudios Manchegos, 1976), 273-296; Teófilo Ruiz, "Images of power in the seals of the Castilian monarchy: 1135-1469", en Estudios en homenaje a don Claudio Sánchez-Albornoz en sus 90 años (Buenos Aires: Fundación Claudio Sánchez Albornoz, 1986), vol. IV, 455-463 y "L'image du pouvoir à travers les sceux de la monarchie castillaine", en Génesis medieval del estado moderno: Castilla y Navarra (1250-1370) (Valladolid: Ámbito, 1987), 217-227; Bonifacio Palacios Martín, "Investidura de armas de los reyes españoles en los siglos XII y XIII", Gladius, vol. especial Primer simposio internacional sobre las armas en la historia (1988), 153-192; María del Pilar Ramos Vicent, "Reafirmación del poder monárquico en Castilla: la coronación de Alfonso $\mathrm{XI}^{\prime \prime}$, Cuadernos de Historia medieval, 3 (1983), 5-36; José Manuel Nieto Soria, Fundamentos ideológicos del poder real en Castilla (siglos XIII-XVI) (Madrid: Eudema Universidad, 1988), 58 y 99 y Ceremonias de la realeza. Propaganda y legitimación en la Castilla trastámara (Madrid: Nerea, 1993), 75; José Luis Martín Rodríguez y Luis María Serrano Piedecasas, "Tratados de caballería. Desafíos, justas y torneos", Espacio, Tiempo y Forma (1991), 161-242; Jesús Rodríguez Velasco, El debate sobre la caballería en el siglo XV. La tratadística caballeresca castellana en su marco europeo (Valladolid: Junta de Castilla y León, 1996), 56, nota 78. séquito de autores y más fundamento en la verdad" 5 .

La sarcástica frase no podía expresar mejor lo que para el autor significaba la participación de un muñeco como tramoya de una ceremonia de coronación real. Sólo unas décadas después, en 1736, se publicaba el grueso volumen que Juan de Saracho dedicó a la biografía de Antonia Jacinta Navarra y de la Cueva, abadesa de Las Huelgas fallecida en 1656. El libro fue editado con un prólogo de José Moreno Curiel -a la sazón clérigo en el convento de la Trinidad de Burgos entre 1732 y 1734-, que trazó un interesantísimo panorama de la vida monástica en las medianías del siglo XVII. En el largo prólogo que precede el relato de su vida, Moreno incluyó una descripción del monasterio, un completo abadologio, la vinculación de la real casa con su fundación y fábrica, la Orden de Císter, el papel de su abadesa y el gobierno de Las Huelgas en su rama femenina. Es en el apartado dedicado a la estrecha relación entre los reyes y Las Huelgas donde, más allá de su fundación y de ser lugar de enterramientos regios, encontramos la que hasta ahora es la segunda alusión en el tiempo a una figura articulada que, siguiendo el relato, era usada en el ceremonial real castellano: "Lucas tudense dice que a este Real convento debe su nombre de Real la cabeza de Castilla, Burgos, quizá porque tantos reyes vinieron a coronarse a él, honra sin duda grandíssima, de que toca su parte a la ciudad. Aún hoy persevera en él la imagen de vulto de Santiago, gozneada en brazos y manos para facilitar su movimiento y ésta, ayudada del arte, les ponía la corona a los reyes y después les daba muchas (sic) contra moros en sus combates" ${ }^{\prime 6}$.

\footnotetext{
${ }^{5}$ Alonso Núñez de Castro, Corónica de los señores Reyes de Castilla, Don Sancho el Deseado, Don Alonso el Octauo, y Don Enrique el Primero. En que se refiere todo lo sucedido en los Reynos de España, desde el año mil ciento y treinta y seis, hasta el de mil y docientos y diez y siete (Madrid: Pablo de Val, 1665), 280.

${ }^{6}$ Continúa el relato de las coronaciones en Las Huelgas, desde Fernando III a Juan I, pasando por Alfonso X, Alfonso XI, y Enrique II, Juan de Saracho y José
} 
Si el trinitario dio por buena la tradición, en 1856 el expediente que se envió desde la Casa real al Ministerio de Hacienda para evitar la Desamortización del monasterio recogió las reales fundación, donaciones y coronaciones, pero no hizo alusión alguna a la figura del Apóstol7. Tampoco Rodrigo Amador de los Ríos, que la dejó en un significativo silencio ${ }^{8}$. Por el contrario, Manuel de Assas siguió el testimonio de Alonso Núñez de Castro en lo relativo a la coronación de Enrique I, pero considerando verídica la tradición y haciéndola también partícipe de la toma de armas de Fernando III. A su entender, la imagen "sirvió para las ceremonias de coronar y armar de caballeros a los reyes" ${ }^{\prime \prime}$. A su vez, Juan Agapito y Revilla planteó una primera valoración estética y cualitativa sobre la pieza, considerándola deleznable y sólo destacable por su posible papel en el ceremonial regio. Si apuntó en nota que la toma de armas de Alfonso XI había sido en Santiago, unas líneas más adelante, al des-

Moreno Curiel, Jardín de flores de la gracia. Escuela de mejor doctrina, vida y virtudes de la prodigiosa y venerable señora doña Antonia Jacinta de Navarra y de la Cueva, abadesa del Ilustríssimo y Real monasterio de las Huelgas, cerca de Burgos, del Orden del Glorioso y melifluo padre san Bernardo, sacada a la letra de los quadernos que, por mandado de sus confessores, dexó ella misma escritos (Burgos: Imprenta de Atanasio Figueroa, 1736), prólogo sin paginar. Sobre el autor, Bonifacio Porres Alonso, Los trinitarios en Burgos. Historias de un convento (1207-1835) (Córdoba: Secretariado trinitario, 2004), 168.

${ }^{7}$ Exposición dirigida al Excmo. Sr. Ministro de Hacienda en nombre y de orden de S. M. la Reina por el intendente de su real casa y patrimonio, para probar así con los privilegios y escrituras de la fundación del monasterio de Santa María la Real de las Huelgas y el Hospital del rey, cerca de Burgos (...) que, siendo propios y patrimoniales de S. M. (...) no deben ser comprendidos en la ley de Desamortización (Madrid: Aguado Impresor de Cámara de S. M. y de su real casa, 1856).

${ }^{8}$ Rodrigo Amador de los Ríos, España, Sus monumentos y artes, su naturaleza e historia. Burgos (BurgosBarcelona: Establecimiento tipográfico de Daniel Cortezo y Cía, 1888).

${ }^{9}$ Manuel de Assas, "Sepulcro de la reina doña Berenguela en el monasterio de Las Huelgas junto a Burgos y noticias históricas y artísticas con motivo de esta monografía acerca de aquel célebre monasterio", Museo Español de Antigüedades, IV (1875), 126-158. cribir la imagen ya entonces localizada en la capilla de su advocación en el conjunto monástico, afirmó: "Es una estatua sedente de mal gusto y de ningún mérito artístico, pero en cambio, es grande el histórico, pues la tradición [de su uso en la toma de armas] parece ser confirmada con los goznes que dan movimiento a los brazos y la posición de la espada sostenida en alto con la mano derecha"10. Por vez primera se hablaba exclusivamente de toma de armas y no de coronación.

Cuatro años después, el capellán e historiador del monasterio Amancio Rodríguez López se planteó la realidad de la imagen al describir la capilla de Santiago, en la que se guardaba la figura: "Entrando en esta capilla vése a la derecha un lienzo en que se demuestra dibujado el Santo Cristo de Burgos y en frente de éste la célebre imagen de Santiago de brazos móviles por medio de un resorte y ante la que, según la tradición, solían verificarse las ceremonias de armarse caballeros los que en este monasterio lo realizaron". A lo que anota al pie añade: "Ni en las crónicas de nuestros reyes, ni en los documentos del archivo hay dato alguno que confirme esta tradición, a la que no damos crédito"11. En 1921, la figura formó parte del elenco de piezas para la exposición realizada con motivo del séptimo centenario del inicio de las obras de la catedral de Burgos. La descripción no tiene desperdicio: "Estatua del Apóstol Santiago, de madera, con juego de brazos, de 1,30 m. de alta [...] Se tiene por del año 1228. Es insignificante como escultura, y si data del citado año, debió ser renovada al policromarla en gusto morisco del tiempo de Alfonso X [...] Servía, según la tradición, para dar el espaldarazo al Rey cuando se armaba caballero en aquel

${ }^{10}$ Juan Agapito y Revilla, El Real Monasterio de las Huelgas de Burgos. Apuntes para un estudio histórico-artístico (Valladolid: Imprenta La Nueva Pincia, 1903), 57, nota 1 y $151-152$.

${ }^{11}$ Amancio Rodríguez López, El Real Monasterio de Las Huelgas de Burgos y el Hospital del Rey (Apuntes para su historia y colección diplomática con ellos relacionada) (Burgos: Imprenta y Librería del Centro Católico, 1907), vol. II, 273. 
famoso monasterio"12. Si bien no se incluyó como ilustración en el catálogo, la escultura sí se fotografió. No hace mucho María José Martínez publicó la foto realizada por Eloy García de Quevedo, conservada en la colección fotográfica del Instituto de Enseñanza Secundaria Conde Diego Porcelos de Burgos (Fig. 2), en la que la imagen aparece retratada sin las mangas que habitualmente cubren sus brazos ${ }^{13}$. Se trata de un testimonio gráfico básico, porque muestra los sistemas de articulación previos a que fueran sustituidos en los años noventa del siglo XX.

¿Pero cuándo se impuso esta corriente generalizada alrededor del ya bautizado como Santiago "del Espaldarazo" como producto de la ceremonia de toma de armas de Alfonso XI? El historiador del teatro John E. Varey fue el primero en conectar nuestra figura con las citas al respecto procedentes de la Crónica de Alfonso XI y, por tanto, considerando que la imagen que dio la pescozada al rey en Compostela según la citada fuente era el Santiago articulado de Las Huelgas ${ }^{14}$. Pero no se trató de una identificación generalizada. En 1971, José María de Azcárate volvía a evocar la toma de armas de Fernando III, ampliando el papel de la imagen a varias ceremonias reales. A diferencia de los restantes autores, la liturgia real pasaba a celebrarse físicamente en la capilla de Santiago, en la clausura monástica, donde la talla se ubicó al menos desde el siglo XIX. A su juicio, este era el lugar idóneo para el ritual de toma de armas, cercano al supuesto palacio real de las "claustrillas", que hoy sabemos se halló en el compás de entrada al monasterio, a los pies de la iglesia ${ }^{15}$. Por su parte, el cro-

${ }^{12}$ Juan Antonio Cortés et al., VII Centenario de la catedral de Burgos, 1921. Catálogo general de la exposición de arte retrospectivo (Burgos: Imprenta Aldecoa, 1926), 4.

${ }^{13}$ Martínez Martínez, “Las imágenes articuladas...”.

${ }^{14}$ John E. Varey, Historia de los títeres en España (Madrid: Revista de Occidente, 1957), 33-34.

${ }^{15}$ José María de Azcárate Ristori, "La capilla de Santiago en Las Huelgas de Burgos", Reales Sitios, 28 (1971) 49-52. Las "claustrillas", en realidad, son el lujoso patio porticado de la enfermería y el palacio abacial

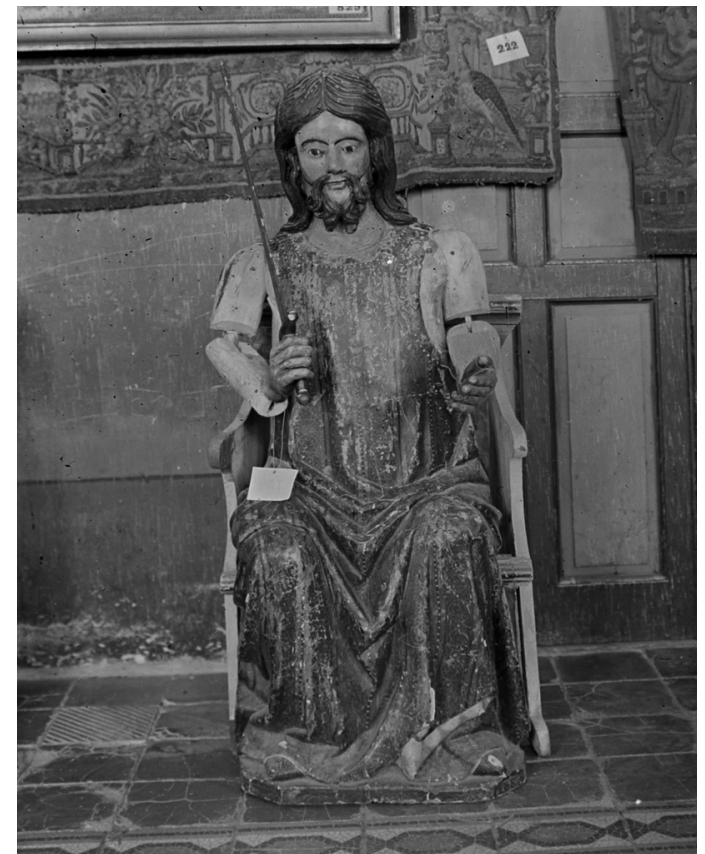

- Fig. 2. Eloy García de Quevedo, Santiago del Espaldarazo en la Exposición de arte de 1921. Foto: Colección fotográfica del Instituto de Enseñanza Secundaria Conde Diego Porcelos, Burgos. http://cincuentenarioporcelos.com/09patr/1fot/ 06otros/06escul/img/6escul/Burgos,\%20monas terio $\% 20$ de $\% 20$ las $\% 20$ Huelgas, $\% 20$ estatua $\% 20$ sedente\%20de\%20Santiago.jpg

nista burgalés fray Valentín de la Cruz prefirió no citar a reyes concretos. La figura sólo era un instrumento para armar caballeros y, aunque siguió la hipótesis de Azcárate en lo relativo a la función de la capilla de Santiago como escenario de la coronación, también planteó que "quizá, en las grandes solemnidades, la estatua era llevada a la nave mayor de la iglesia para el desarrollo pomposo de la liturgia"16.

Los historiadores que trabajaron las ceremonias reales en fechas inmediatas también dieron por buena la tradición de una imagen articulada de Santiago que corona-

del monasterio, cf. Eduardo Carrero Santamaría, "Epigrafía y liturgia estacional entre el locutorio y el pasaje a la enfermería de la abadía de Santa María la Real de las Huelgas, en Burgos", Territorio, Sociedad y Poder, 9 (2014), 117-132.

${ }^{16}$ Valentín de la Cruz, El monasterio de Las Huelgas de Burgos (León: Everest, 1990), 62. 
ba o daba pescozadas ${ }^{17}$. Peter Linehan fue más allá siguiendo la propuesta de Varey aunque, interpretando en su favor un documento, afirmó que la estatua había sido hecha por voluntad real para investir a Alfonso XI, quien también habría mandado su traslado a Compostela para la ceremonia. El supuesto refrendo diplomático a la hipótesis en realidad sólo era el producto de su confusión alrededor de un registro publicado por Bonifacio Palacios, en el que se recoge cómo el rey había llevado "paños de oro y seda, pelles arnesia ac jocalia". El lógico ajuar para acto semejante, pero que nada dice respecto a la imagen del Espaldarazo ${ }^{18}$.

Rocío Sánchez Ameijeiras también consideró la toma de armas de Alfonso XI como el factor básico para la talla. Por primera vez se daba una datación tardía de la pieza, en el segundo cuarto del siglo XIV, y destacando algo tan interesante como que la imagen se halla en Burgos y no en Santiago, donde el monarca se armó caballero. Por lo tanto, "como memoria de dicho acontecimiento [la toma de armas] pudo haber sido labrada la pieza burgalesa, para presidir la fastuosa ceremonia de coronación que tuvo lugar pocos días después en Las Huelgas, tras la cual fueron armados caballeros, por mano del rey, muchos ricoshombres"19. Una interesante puntualización.

La cosa no quedó aquí. Nelly R. Porro Girardi interpretó la entrada de Alfonso XI en caballería una investidura "a lo divino", motivada por la necesidad del rey de conectar su reinado y, en este caso, su toma de armas nada menos que con el Santo patrón Santiago y en su catedral, ante la desconfianza de una nobleza levantisca. Respecto al tan traído y llevado rol de la imagen en la liturgia regia, la autora negó su uso en el ceremo-

\footnotetext{
17 Véase la nota 4.

${ }^{18}$ Palacios Martín, “Los símbolos...”, 289 y 294-296. Linehan, “Ideología y liturgia...”, 236.

${ }^{19}$ Rocío Sánchez Ameijeiras, "Santiago del Espaldarazo", en Santiago, camino de Europa. Culto y cultura en la peregrinación a Compostela (Santiago de Compostela: Fundación Caja Madrid, 1993), 420-421.
}

nial insistiendo en que, al contrario de lo que habían considerado otros autores, no tenía dispositivos mecánicos y algo mucho más importante: el hierro que sostiene en su brazo derecho no tiene razón de ser ya que, en las tomas de armas, el golpe de espada sustituyó a la pescozada que se aplicaba con la mano en fechas muy posteriores a 1332, año del armamento y coronación del rey Alfon$\mathrm{so}^{20}$. Tras ella, y para apuntar los problemas funcionales que la capilla de Santiago suscita en la topografía del monasterio, apoyé la discusión cuestionando la realidad histórica de la talla y, también, de una capilla que más tiene de privativo espacio funerario que de ámbito para ceremoniales regios. Después, a la hora de estudiar el uso arquitectónico de la catedral de Santiago siguiendo el Libro de la Coronación de los Reyes de Castilla (Real Biblioteca del Escorial), volví sobre el tema destacando la imposibilidad de identificar el Santiago del Espaldarazo con la expresión utilizada en la crónica real para la toma de armas, de la que trataremos más adelante. Además, apunté la posibilidad de buscarle otro origen a la pieza, basado precisamente en la importante historia moderna del monasterio y el episodio de intento de canonización de los reyes fundadores ${ }^{21}$.

${ }^{20}$ Nelly R. Porro Girardi, La investidura de armas en Castilla. Del Rey Sabio a los Reyes Católicos (Valladolid: Junta de Castilla y León, 1998), 113-121 para el lugar de la coronación y 281-282 y 285-287, centrada en la de Alfonso XI en Santiago y nuestro artilugio articulado. También Georges Daumet, "L'ordre castillan de l'Écharpe (Banda)", Bulletin Hispanique, 25 (1923), 5-32.

21 Eduardo Carrero Santamaría, “Observaciones sobre la topografía sacra y cementerial de Santa María la Real de las Huelgas, en Burgos, y su materialización arquitectónica", en La clausura femenina en España. Actas del Simposium, (San Lorenzo del Escorial: Instituto Escurialense de Investigaciones Históricas y Artísticas, 2004), vol. II, 695-715; "Por Las Huelgas los juglares. Alfonso XI de Compostela a Burgos siguiendo el Libro de la coronación de los reyes de Castilla", Medievalia. Revista d'estudis medievals, 15 (2012), 143-157; "Architecture and Liturgical Space in the Cathedral of Santiago de Compostela. The Libro de la Coronación de los Reyes de Castilla", Hispanic Research Journal, 13 (2012), 466-486 y "The Creation and use of space in the Abbey of Santa María la Real de Las Huelgas, Burgos: architecture, 
Siempre desde la Historia del arte, ahora Joaquín Yarza también se cuestionó la autenticidad de todo el conjunto, desde la imagen hasta su escenario en la capilla monástica de Santiago, percibiendo que algo no casaba. En primer lugar, la iglesita de Santiago -localizada al este del complejo arquitectónico de Las Huelgas- era un reducido espacio que no parecía el más apropiado para una liturgia de exaltación real o nobiliaria y cuya cronología tampoco parecía casar con tomas de armas como la de Eduardo de Inglaterra en 1268. La gran ceremonia por la que el séquito de Alfonso XI fue armado caballero en 1332 se hizo en la iglesia del monasterio y de mano del propio rey, como indica la crónica. Tampoco intervenían aquí la capilla ni, por descontado, la talla. Por otra parte, la singular traza de la imagen -sin más elementos iconográficos que la solitaria espada-, le hicieron pensar que "cabe incluso la duda de que haya tenido brazos articulados. Podría haber sido una imagen de Cristo que, en un tiempo indeterminado pero posterior a la primera mitad del siglo XIV, se convirtiera en lo que hoy parece ser" ${ }^{\prime 22}$. Sus dudas se vieron confirmadas con la restauración de la pieza. La obra pasó por taller destapándose un escenario material inaudito: el Santiago del Espaldarazo en realidad era una adaptación de una antigua Virgen a la que se habían amputado los brazos y el niño del regazo, instalándosele otros brazos ahora articulados y una barba hecha de "pasta de yeso mate, cola animal y estopa" ${ }^{23}$.

liturgy, and paraliturgy in a female Cistercian monastery", Journal of Medieval Iberian Studies, 29 (2014), 1-23.

22 Joaquín Yarza Luaces, "Monasterio y Palacio del Rey", en Vestiduras ricas. El monasterio de Las Huelgas y su época 1170-1340 (Madrid: Patrimonio Nacional, 2005), 15-34. Parece que la talla ya había sido intervenida en 1963, en el marco de una restauración integral de la capilla, Pilar Alonso Abad, El Real monasterio de Las Huelgas. Historia y arte (Burgos: Patrimonio Nacional-Caja Círculo, 2007), 349.

${ }^{23}$ Torrón Durán, "Imagen de Santiago...", 74.
LOS HECHOS. HISTORIA DE UNA RESTAURACIÓN Y DIVULGACIÓN DE SUS HALLAZGOS

Llegados a este punto conviene hacer una pequeña recapitulación. En Las Huelgas de Burgos se conserva una imagen vestidera sedente, de un personaje barbado. Cuenta con 1,22 metros de alzada por 0,54 y por 0,37 de anchura y profundidad. Los brazos están articulados en el hombro, codo y muñecas y cubiertos por unas mangas de tela que se enganchan en los hombros y a las sisas del pellote que viste. En la mano derecha sostiene una espada, mientras mantiene la izquierda con la palma abierta. Parece que las mangas no fueron su vestimenta original. En el primer testimonio fotográfico de la imagen, de 1921 (Fig. 2), aparece con los brazos al descubierto. Todo parece indicar que debió vestirse con un traje completo, que también cubriera un cuerpo muy maltratado hasta su restauración en el siglo XX.

Como vimos en los apartados previos, la tradición convirtió la imagen en una suerte de marioneta representando al Apóstol Santiago que, según qué autor, fue utilizada ya para armar caballero ya para coronar al rey de Castilla, quien no tenía a bien la presencia de intermediarios en su recepción de poderes. Las noticias más tempranas al respecto datan de la segunda mitad del siglo XVII, cuando el cronista de Felipe IV Alonso Núñez de Castro ya consideraba la historia una patraña. En sus tiempos se le atribuía haber sido usada para coronar a Enrique I, el malogrado hijo de Alfonso VIII. Y es que tanto la ceremonia como la identidad del monarca han tardado en fijarse. Por un lado, daba igual que se tratase de una toma de armas como de una coronación, hasta que la historiografía del siglo XX determinó que la imagen sirvió para armar caballeros. Su cronología hizo dudar a los historiadores más antiguos, como Alonso Núñez de Castro o Miguel Novoa y Varela, que la hicieron participar de la coronación de Enrique I (†1217) 
y de Fernando III (†1252), respectivamente ${ }^{24}$. Ambos reinados acontecieron más de un siglo antes de la presunta talla de la imagen. Además, los dos escritores insistieron en que la tradición era la única fuente a la que podían referirse. Varios reyes fueron armados caballeros en Las Huelgas, por lo tanto, la imagen parecía ser perfecta para cualquiera de ellos. Y fue precisamente adscrita a uno de los monarcas que entró en caballerías fuera de Burgos, Alfonso XI, que se armó ante el altar mayor de la catedral de Santiago.

Los historiadores del arte sitúan su elaboración en un marco hipotético entre el último tercio del siglo XIII y la segunda mitad del XIV. Si unos aluden al tipo de imagen sedente como propia de las medianías del XIII, otros prefieren llevarla al siglo XIV. Para Yarza, estilísticamente la figura se sitúa en el entorno de los talleres activos en las dependencias del claustro de la catedral de Burgos, pasado entonces el año $1300^{25}$. Mientras, Rosa Rodríguez Porto evoca modelos trecentistas para los rizos de la barba ${ }^{26}$. Al contrario que las articulaciones, las manos o la espada -clara obra moderna-, la barba no propicia establecer fechas en función de estilo. Incluso, si la relacionamos con barbas de implicación regia, como la del Alfonso XI de la catedral de Oviedo o las de los personajes masculinos de la coetánea portada de Sasamón, infinitamente más elaboradas. La del Santiago del Espaldarazo no es más que una simple barba partida en dos guedejas rizadas, generalizada entre los siglos XIII y XVI y que, por tanto, no admite ser tratada como elemento de datación absoluta o caeremos en la tram-

${ }^{24}$ Núñez de Castro, Corónica, 280 y Miguel Novoa y Varela, Un recuerdo glorioso de las Huelgas de Burgos (Madrid: Tipografía de los Huérfanos, 1887).

25 Sánchez Ameijeiras, "Estatua de Santiago del Espaldarazo...", 470; Clara Fernández-Ladreda Aguadé, "La imaginería en los monasterios cistercienses castellano-leoneses", en Monjes y monasterios. El Císter en el medievo de Castilla y León (Valladolid: Junta de Castilla y León, 1998), 411-426 y Yarza Luaces, "Monasterio y Palacio...", 26.

${ }^{26}$ Rodríguez Porto, "Mística regia y ambiciones compostelanas..." y "Knighted by the Apostle...". pa de considerar como medieval lo que sólo es tosco. ¿Por qué entonces Alfonso XI?, ¿por una cuestión de estilo basada en unas barbas de pasta y estopa o por la interpretación de la crónica real en la que el rey recibe el espaldarazo de una imagen del Apóstol, considerada como inequívoca referencia a la figura burgalesa? Bien parece que estemos oyendo campanas...

Entre el 1 de marzo y el 28 de junio de 1993 se llevó a cabo una restauración de la pieza, con el fin de su muestra en la exposición Santiago, camino de Europa, que tuvo lugar en el monasterio compostelano de San Martín Pinario. Según veíamos atrás, los resultados más sorprendentes obtenidos de la intervención fueron publicados por Francisco Torrón Durán, pero el expediente completo de la restauración, ahora firmado por Enrique Suárez Núñez, se conserva en el Departamento de restauración de Patrimonio Nacional, en el Palacio Real de Madrid ${ }^{27}$. Siguiendo el informe, la figura está realizada en madera de cerezo, en tanto que los brazos que se le acoplaron son de pino. En el momento de llegar al taller, ya carecía de cátedra o asiento ninguno, estando situada sobre un sitial cúbico de aglomerado tapizado, es decir, que desde hace tiempo se halla fuera de su contexto escultórico original e inmediato. Toda la figura estaba muy dañada en superficie, con numerosas pérdidas de policromía y varias grietas, las dos más importantes en cabeza y hombros, íntimamente ligadas a su transformación de Virgen en Apóstol. En el costado izquierdo se había estucado una zona rectangular en forma de siete donde habría estado colocada la pieza que sustituyó al Niño (Figs. 3 y 4).

Una de las noticias más perturbadoras del informe es la relativa a la lectura de la imagen con infrarrojos, que delataba cómo

27 Patrimonio Nacional (PN), Departamento de Restauración, Taller de escultura, Exp. no 1/93. Con mi agradecimiento a María Jesús Herrero Sanz y Concha Herrero Carretero por facilitarme su consulta y gestionar lo derechos de reproducción de las imágenes que acompañan este artículo. 


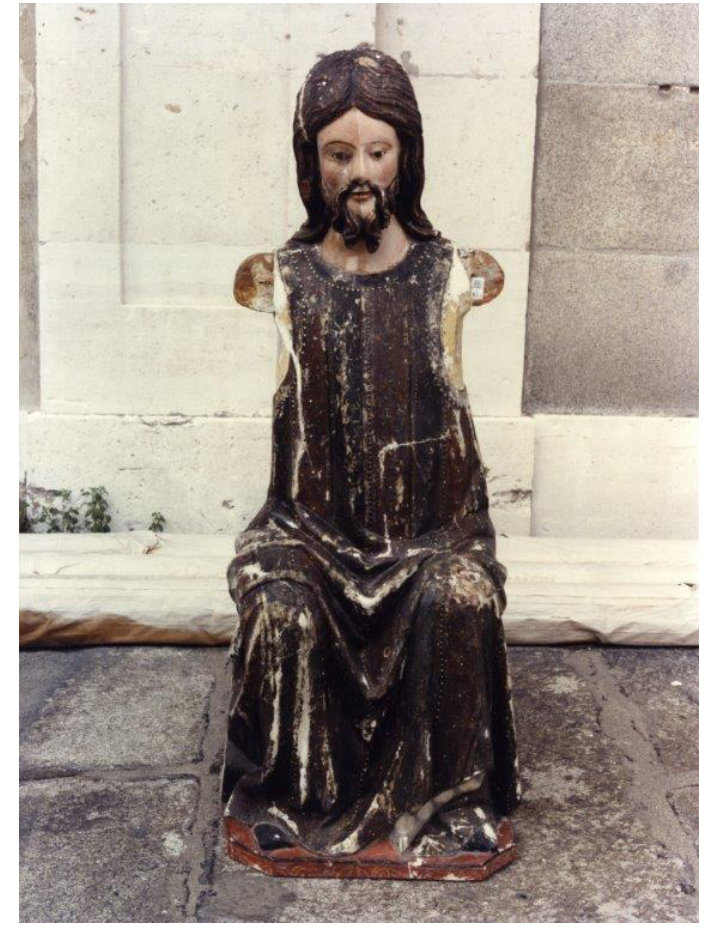

- Fig. 3. Santiago del Espaldarazo. Vista frontal durante el proceso de restauración. Foto: Patrimonio Nacional.

había padecido un gran número de intervenciones previas entre estucados, reintegraciones y repintes en un $70 \%$ de su superficie, junto al añadido de la barba ${ }^{28}$. Así, la grieta de la espalda a la altura de los hombros y que corta la melena fue motivada por la intervención que cortó los brazos e instaló los pernos de madera para los brazos móviles, como recoge la memora de restauración: "por ser el borde superior de la tapa posterior, que se separó al estar empujando los tacos y cuñas de madera, introducidos como soporte de los brazos articulados" (Fig. 5). Esta misma actuación fue la que también generó dos grietas más con diferente dirección, ahora en el hombro, junto al relleno de yeso que integró parte de la actuación tardía (Fig. 6). La grieta de la cabeza es especialmente interesante ya que delata algo que hasta la fecha había pasado desapercibido y es que la figura contó con un nimbo o una corona, posiblemente metálicos. Este añadido obligó a taladrar la zona superior, motivando

${ }^{28}$ PN, Departamento de restauración, Taller de escultura, Exp. no 1/93.

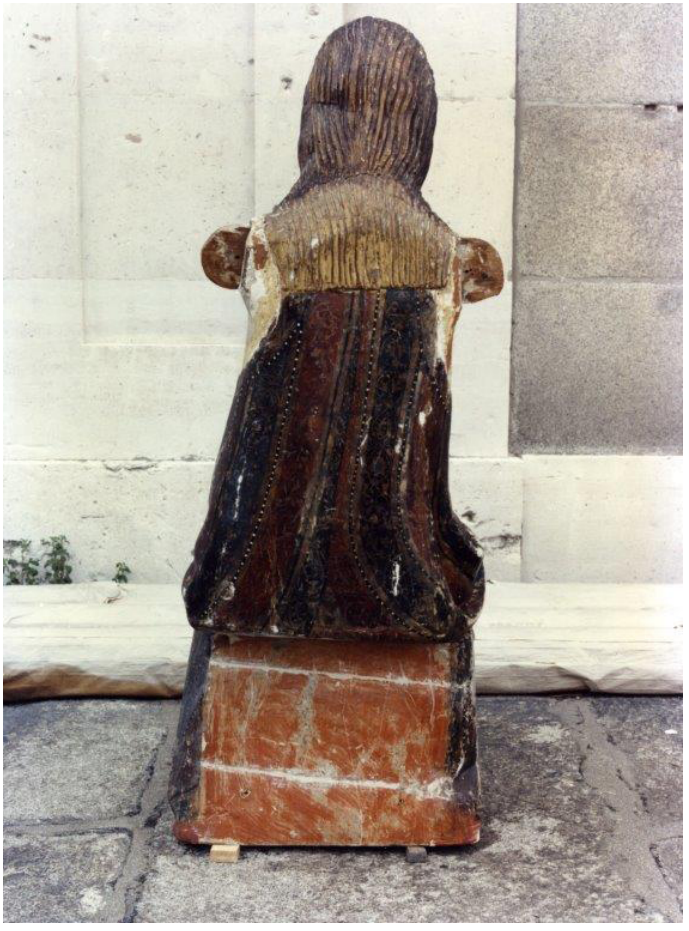

- Fig. 4. Santiago del Espaldarazo. Vista trasera durante el proceso de restauración. Foto: Patrimonio Nacional.

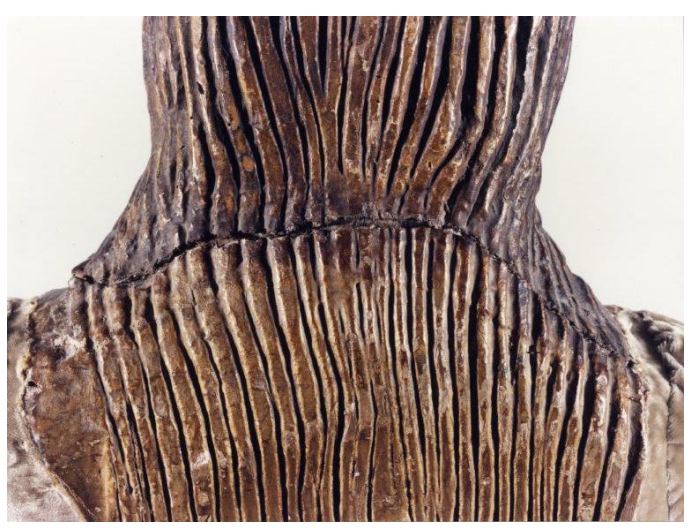

- Fig. 5. Santiago del Espaldarazo. Vista de la grieta en la espalda, a la altura del cuello Foto: Patrimonio Nacional.

daños claros en la imagen, como la citada grieta que rodea su lado derecho: “Otra grieta notable es la que recorre gran parte del pelo en el lado derecho de la cabeza (...) En la parte superior se observan unas hendiduras, posiblemente causadas para colocar una corona, limbo (sic), potencias, etc." La espada, de madera, estaba rota y había perdido zonas del estucado. Al desmontarse las manos, pudo comprobarse que al igual que la espada se trataba de piezas claramente 
modernas (Fig. 7). Además, durante la intervención se realizó una reconstrucción facial, básicamente en el ojo derecho, cejas y labios. Se repusieron los antebrazos y los pasadores metálicos de las articulaciones, que estaban doblados y oxidados. Además, se reforzaron las rótulas de brazos y manos, poniéndose nueva la del antebrazo y brazo izquierdo, en madera de haya.

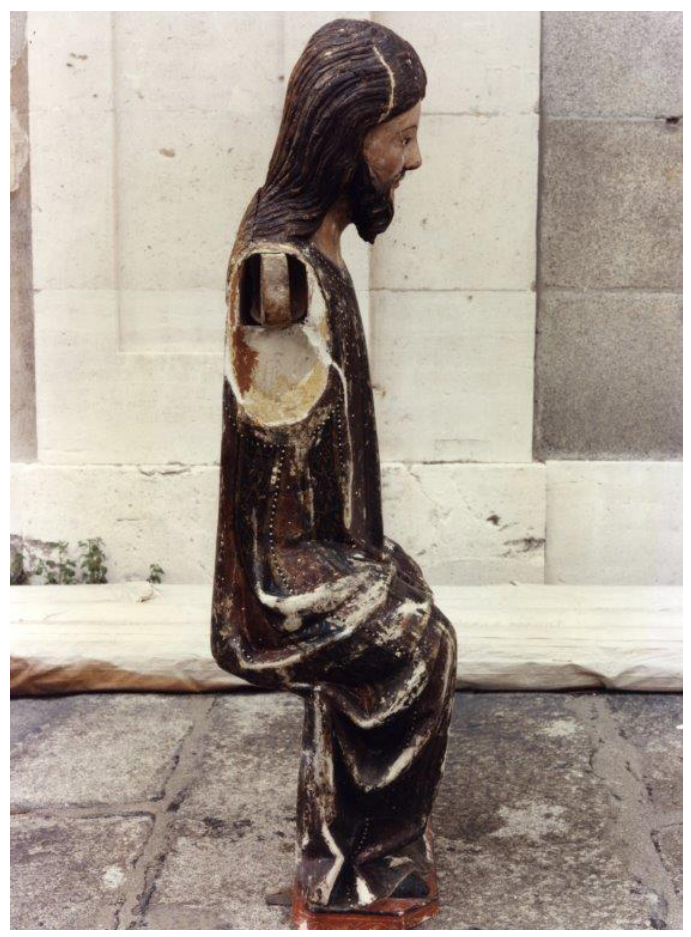

- Fig. 6. Santiago del Espaldarazo. Perfil izquierdo durante la restauración. Foto: Patrimonio Nacional.

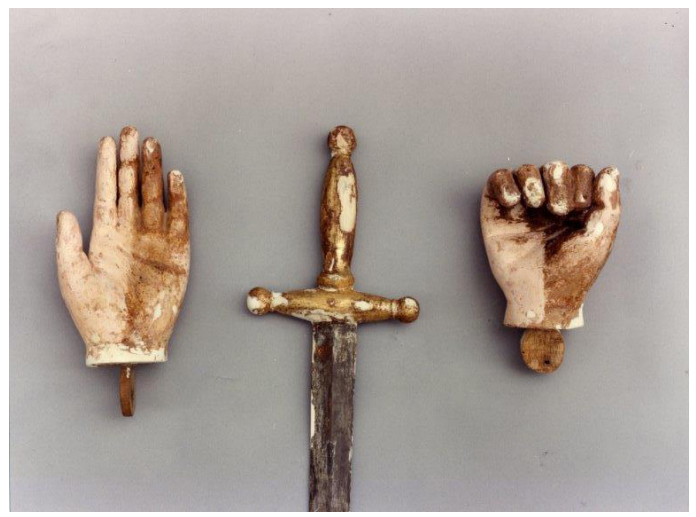

- Fig. 7. Santiago del Espaldarazo. Manos y espada desmontadas durante el proceso de restauración. Foto: Patrimonio Nacional.
Las catas en la policromía dieron a conocer que la imagen originalmente tuvo cabello y barba dorados. Aparecieron restos de pigmento amarillo-dorado como preparación y, por encima de este, restos de oro, que contribuirían a dar una estampa muy diferente de la actual y quizás estarían hablándonos de una cronología tardía, en virtud de la generalización del dorado para el cabello. Aunque lo más importante sea constatar que no sabemos si se trató de su color original como Virgen o el de su transformación en caballero. En cualquier caso, el restaurador no se planteó la posibilidad de restituirlo para evitar el choque visual respecto de los repintes posteriores, "además de no poder determinar si habría o no cantidad suficiente de restos de pelo rubio para justificar la eliminación del tono presente".

\section{IMÁGENES LITÚRGICAS MÓVILES}

La imagen de Santiago del Espaldarazo no es la más antigua imagen religiosa articulada ni, por supuesto, la primera vestidera. Hay suficientes noticias sobre prodigios visuales generados alrededor de imágenes sagradas desde tiempos tempranos ${ }^{29}$. Y, en lo que respecta a la usanza de vestir las imágenes, esta ya aparece regulada en la número 295 de las Cantigas alfonsíes, cuando describen al rey "que sas figuras / mandava sempre fazer / muit'apostas et fremosas / et facía-las vestir / de mui ricos panos d'ouro / et de mui nobre lavor (...) e outrossí nas sas festas / as fazía-lle mudar / sempr'outos panos mais ricos / pola festa mais onrrar". La sevillana Virgen de los Reyes -la más hermosa talla vestidera de todo el siglo XIII europeo- y la cantiga en cuestión han llevado a pensar que la costumbre se desarrolló y generalizó precisamente en la capital andaluza, donde conservamos el mayor número de

${ }^{29}$ Remito a los capítulos dedicados al respecto en el clásico de David Freedberg, El poder de las imágenes. Estudios sobre la historia y la teoría de la respuesta (Madrid: Cátedra, 1992). 
imágenes marianas medievales destinadas a ser vestidas ${ }^{30}$.

Por encima de casos puntuales, el uso generalizado de imágenes en ceremonias litúrgicas teatralizadas -como los cristos que participaban en las ceremonias del Triduo Sacro, desde el desenclavo al entierro-, no fue en paralelo con la difusión de sus sistemas de articulación. La gran mayoría de estas figuras eran yacentes de una sola pieza o grupos del Descendimiento que, depositados en capillas durante el resto del año, eran sacados a escena durante la Semana Santa, sirviendo como depósito a modo de sepulcro de las hostias consagradas para el Viernes Santo y su liturgia de especies presantificadas. En este sentido, hay una confusión generalizada entre cristos articulados y grupos monumentales del Descendimiento. Estos últimos -habituales desde el siglo XII- no deben confundirse con el efectivo uso de una imagen articulada que se bajaba de la cruz y que, a todas luces, no parece poder datarse antes de la segunda mitad del siglo $\mathrm{XIV}^{31}$. Desde el quinientos, y muy especialmente con el desarrollo de la liturgia postridentina, las ceremonias del Desenclavo y el santo Entierro se consolidaron en la Semana Santa barroca y motivaron la transformación de viejas tallas de crucificados y yacentes que fueron dotados de brazos articulados para hacerlos descender de la cruz y depositarlos en un sepulcro.

Volviendo al Santiago del Espaldarazo, no hay rastro del teórico dispositivo al que en alguna ocasión se ha aludido y que haría moverse los brazos de la imagen. En el apar-

\footnotetext{
${ }^{30}$ Propuesta que recoge Joaquín Arquillo Torres, "Aspectos socio-religiosos en la conservación de las representaciones escultóricas marianas. Influencia en tres imágenes representativas" (tesis doctoral, Sevilla, 1989), 32 , enlace web.

31 Véase el trabajo de Francesca Español, "Los descendimientos hispanos", en La Deposizione lignea in Europa. L'immagine, il culto, la forma (Perugia: Electa, 2004), 511-554. Sobre la costumbre creciente de 1400 en adelante, Felipe Pereda, Las imágenes de la discordia. Política y poética de la imagen sagrada en la España del cuatrocientos (Madrid: Marcial Pons Historia, 2007), 105-106.
}

tado previo vimos que el cuerpo es macizo y que sus brazos se articulan mediante goznes tallados en la madera cruzados por un pasador. No es un autómata, no hay dispositivos ocultos, son sólo dos brazos articulados en hombro, codo y muñecas para vestirlo y colocarlo. Supongo que el mecanismo en rueda que permitía mover y fijar las cabezas de la Virgen de los Reyes de Sevilla y de su Niño Jesús hizo dispararse la imaginación de quienes no tuvieron acceso visual a la pieza sin su suerte de jubón. La escena, ciertamente extravagante, de un marionetista moviendo los brazos del Apóstol para dar el espaldarazo al rey pudo hacer pensar en una maquinaria que lo accionara. Así, se movería de igual manera a como a veces se imaginaba que actuaban las imágenes sevillanas, como autómatas o marionetas, en una suerte de teatrillo en el que participaban junto a las imágenes sedentes de Fernando III, Beatriz de Suabia y Alfonso X, a las que acompañaban en el monumental conjunto de la capilla real de la catedral de Sevilla.

El estudio comparado de los mecanismos de articulación es el que realmente puede aportarnos cronologías aproximadas. De hecho, el quid de la cuestión sobre la transformación de la Virgen de Las Huelgas en el supuesto Apóstol se encuentra en sus articulaciones. Las de las imágenes de Cristo más antiguas a las que ahora aludíamos se realizaron mediante diferentes modelos de goznes en punta que, enlazados o asociados a pletinas metálicas, eran clavados o insertados en las maderas, actuando como rótula de movimiento ${ }^{32}$. En el caso del Santiago burgalés, el método utilizado fue la llamada articulación de galleta, en la que una pieza circular se acopla en una ranura practicada en el miembro $u$ hombro y que cruza un pasador, quedando ambas ensambladas en una rótula. En nuestra imagen, la actuación

\footnotetext{
${ }^{32}$ Luis Cristóbal Antón, "Conservación y restauración de esculturas de madera", en Actas de los VIII cursos monográficos sobre patrimonio histórico, Reinosa, julio-agosto, 1997, ed. por José Manuel Iglesias Gil (Reinosa: Universidad de Cantabria-Ayuntamiento de Reinosa, 1998), 193-208.
} 
para suprimir los brazos fijos e instalar los móviles fue especialmente traumática, como podemos ver en su lateral izquierdo (Fig. 6), en el que se ahondó sobre el lateral del abdomen dejando espacio suficiente para el nuevo brazo y el libre movimiento de los ropajes, en tanto que en los hombros se injertaron tacos con la galleta en la que se iba a encajarse el brazo, fijado con su espiga o pasador correspondiente. El movimiento de arriba abajo de esta articulación facilitaba el paso de las mangas del vestuario. Por su parte, los brazos tenían su propia galleta que articulaba los codos, como podemos ver en la foto de 1921. En las muñecas, son las manos las que ensamblan sus respectivas galletas en los antebrazos, atravesados después por el pasador correspondiente. A pesar de haberse querido relacionar con las articulaciones de otras piezas medievales bien datadas, como la Virgen de los Reyes de Sevilla y su Niño Jesús, lo cierto es que la articulación en galleta no puede llevarse más allá de la segunda mitad del siglo XV. No en vano, las imágenes de la capilla real sevillana muestran articulaciones con espigas tanto en hombros, codos y muñecas, como en las ingles y rodillas, pero se trata de un trabajo preciosista, en el que la articulación llega a ser disimulada en la cubierta tallada en la propia pieza, que encaja y que oculta parcialmente las rótulas móviles ${ }^{33}$. Volviendo a nuestro Santiago y su ruda transformación, a nadie escapa que las manos y la espada son modernas (Fig. 7). Si, como la restauración demuestra, el tipo de machihembrado mediante piezas en galleta

\footnotetext{
${ }^{33} \mathrm{Al}$ respecto María Teresa Laguna Paúl, "La Virgen de los Reyes", en Maravillas de la España Medieval. Tesoro sagrado y monarquía, coord. por Isidro G. Bango Torviso (Valladolid: Junta de Castilla y León, 2001), vol. I, 435 y "Devociones reales e imagen pública en Sevilla", Anales de Historia del Arte, 23, no especial (II) (2013), 127-157. Insistiendo en la pequeña obra de ingeniería de las articulaciones, María Teresa Laguna Paúl, “Dibujos de la Virgen de los Reyes conservados en la colección Gestoso", Laboratorio de arte, 29 (2017), 617-634. Es muy interesante ver cómo hubo un corpus de imágenes paralelas de características semejantes: José Hernández Díaz, La Virgen de los Reyes, patrona de Sevilla y su archidiócesis. Estudio iconográfico (Sevilla: Imprenta Suárez, 1947), (reed. Sevilla: Guadalquivir, 1996).
}

es el mismo que el de los codos y hombros, no queda lugar a la duda: la transformación de la imagen fue coetánea a la elaboración de las manos y, como estas, sólo puede ser fechable en tiempos modernos. Añadamos a esto la nota diplomática: ninguna descripción de la paraliturgia regia en el monasterio burgalés cita en momento alguno ni la capilla de Santiago ni su imagen del espaldarazo. Es el asunto que nos ocupará el siguiente apartado.

\section{ENCIMA DEL ALTAR. UN PROBLE- MA DE INTERPRETACIÓN}

Haciendo un brevísimo relato sobre las implicaciones del monasterio de Las Huelgas de Burgos en el ceremonial regio, allí fueron armados caballeros en pleno siglo XIII Fernando III de Castilla, el príncipe Eduardo de Inglaterra y es posible que los hijos del rey de Acre, Rodolfo de Habsburgo, el infante Fernando de la Cerda, sus hermanos Juan y Pedro, el infante don Jaime y otros personajes, siguiendo la atribución de Nelly R. Porro ${ }^{34}$. A partir de aquí, las ceremonias más espectaculares que tuvieron el monasterio como proscenio fueron las celebradas por y para Alfonso XI quien, tras armarse caballero en Santiago de Compostela en 1332, se coronó en Las Huelgas en una aparatosa ceremonia, invistiendo personalmente a un grupo de caballeros en la iglesia del monasterio.

El papel de Las Huelgas en los ritos reales continuó. Enrique II fue también a coronarse allí, tras ser proclamado rey en Calahorra. Juan I lo hizo de forma ostentosa, coronándose junto a su esposa, nombrando caballeros a cien de sus hombres y celebrando después "grandes fiestas en la cibdad de Burgos." Por fin, Enrique III adelantó su mayoría de edad declarándose rey en Las Huelgas, antes de los catorce años ${ }^{35}$. En ninguna

\footnotetext{
${ }^{34}$ Porro Girardi, La investidura de armas en Castilla..., 115

${ }^{35}$ Carrero Santamaría, “Observaciones sobre la topografía sacra...", 714 .
} 
ocasión se alude a una figura del Apóstol Santiago que sirviera para dar un simbólico espaldarazo al postulante ni que interviniera en coronación alguna. De hecho, cuando Fernando III pareció inaugurar la costumbre, una de las fuentes al respecto indica que, en realidad, fue su devoción a la Virgen la que le llevó a elegir Las Huelgas, monasterio mariano, como el lugar en que armarse caballero. Se trata de la cantiga 292, al narrar la donación real del anillo a la Virgen de los Reyes de Sevilla: "Mas ponnan-mi en gẽollos, e que lle den o anél, / ca dela tiv' éu o reino e de séu Fillo mui bél, / e sõo séu quitamente, pois fui cavaleir novél / na sa eigreja de Burgos do mõesteiro reial". La Crónica del rey es explícita al narrar la boda del monarca con Beatriz Hohenstaufen en la catedral burgalesa y la inmediata ceremonia de la toma de armas en Las Huelgas, oficiada por el obispo Mauricio, en la que el rey tomó y ciñó por su propia mano espada y cinturón, sin necesidad de otra mano humana que la de su madre, la reina Berenguela, que se ocupó de desceñirle: "et la missa pusieron las armas del rey don Fernando sobre el altar, et dicha la misa et onrrada desse obispo don Mauriç como conuinie, bendixo las armas de la cauallería del rey don Fernando, et sanctiguolas, et pues que fueron bendichas et sanctiguadas, el rey don Fernando tomó del altar su espada, et se la cinxió con su mano misma et cinnósela como a armar cauallero, et la noble reyna donna Berenguela, su madre, se la decinxóno

Pero como venimos anunciando, el problema lo suscita la ceremonia por la que Alfonso XI de Castilla fue armado caballero en Santiago de Compostela. Su presencia en la catedral le convertía en peregrino y, además, ponía parcialmente en práctica lo que el llamado Libro de coronación que para él habían compuesto preveía como una monumental ceremonia real en la que habría tomado las armas y habría sido coronado en un escena-

\footnotetext{
${ }^{36}$ Cit. Eugenio López Aydillo, Los cancioneros gallego-portugueses como fuentes históricas (con un glosario de voces del gallego arcaico) (Nueva York-París: Revue Hispanique, 1923), 48.
}

rio tan simbólico como la ciudad apostólica $\mathrm{y}$, sobre todo, su catedral ${ }^{37}$. A nadie escapa que, tanto en las intenciones del libro como en el propio ceremonial propuesto, había mucho de reivindicativo, de gran espaldarazo -valga la alusión al rito de las armas- para un joven rey cuya minoría de edad fue una pesadilla en un medio político tan adverso como la Castilla de don Juan Manuel. Su abuela, la gran María de Molina, pudo estar detrás de todo este entramado político-litúrgico en el que, mediante un destacado apoyo en el vecino reino de Portugal a los legítimos intereses sucesorios del hijo de Fernando el Emplazado, el Apóstol se convertía en el divino garante del nuevo monarca ${ }^{38}$. El Libro de la coronación quedó inacabado, con unas torpes miniaturas que sólo se pergeñaron hacia la mitad del libro para acabar en grandes espacios vacíos en los folios finales. En paralelo, la gran ceremonia de entrada en las armas y coronación que se proyectaba en Compostela tampoco tuvo lugar. Llegado el momento, se decidió dividirla en dos, dotándola aún si cabe de un mayor contenido simbólico. Por un lado, el rey se armó efectivamente en Santiago, pero la coronación tuvo lugar en Las Huelgas de Burgos, el monasterio ligado a la memoria de la casa real castellana.

\footnotetext{
${ }^{37} \mathrm{El}$ trabajo de referencia al respecto sigue siendo el viejo artículo de Claudio Sánchez-Albornoz, "Un ceremonial inédito de coronación de los reyes de Castilla", Logos, 3 (1943), 75-97, reed. en Viejos y nuevos estudios sobre las instituciones medievales españolas (Madrid: Espasa-Calpe, 1976-80), vol. II, 1209-1236.

${ }^{38}$ Se trató de un vuelco en la política interior frente a la hasta entonces centralización en Toledo, característica destacada para el denominado "molinismo" que, todo sea dicho, volvió a ser puesto en práctica con la fundación de la capilla real en la catedral de Toledo por Enrique II, hijo natural de Alfonso XI y primer monarca de la dinastía Trastámara. El "molinismo" ha sido definido en Fernando Gómez Redondo, "El molinismo: un sistema de pensamiento letrado (1284-1350)", en Estudios de literatura medieval: 25 años de la Asociación Hispánica de Literatura Medieval, coord. por Antonia Martínez Pérez y Ana Luisa Baquero Escudero (Murcia: Universidad de Murcia, 2012), 45-81.
} 
En su momento me ocupé del marco arquitectónico de la ceremonia de toma de armas y coronación en la catedral del Apóstol, previsto en el ritual del Libro de la coronación, y su final puesta en escena en dos escenarios diferentes. La importancia de la catedral apostólica como escenario político para potenciar el reinado es innegable, tanto como la adquisición de un significado simbólico aún mayor con la bilocación del rito entre toma de armas y coronación, realizadas en Compostela y Las Huelgas, respectivamente ${ }^{39}$. En una reciente publicación, Peter Linehan me atribuye el desconocimiento de la doble ceremonia de toma de armas y coronación de Alfonso XI. Quizás se debe a una lectura sesgada e incompleta de los artículos que cita, puede que por un problema de comprensión lingüística al confundir que el ceremonial del Libro de la coronación localiza los dos ritos en Compostela, aunque luego se desdoblaran entre Galicia y Castilla. Dejando a un lado si realmente leyó los trabajos que critica, Linehan vuelve a interpretar en su interés la frase de la Crónica de Alfonso XI, a la que se agarran los adeptos a seguir considerando el Santiago del Espaldarazo la imagen que introdujo en armas a Alfonso XI en Compostela. Según la crónica, a pesar de la redacción de un Libro de la coronación, el rey Alfonso decidió coronarse en Burgos, tomando previamente las armas en Santiago. Siguiendo el texto, durante la toma de armas en la catedral compostelana, el rey había "tomando él por si mesmo todas las armas del altar de Sanctiago, que ge las non dio otro ninguno: et la imagen de Sanctiago, que estaba encima del altar, llegóse el Rey a ella, et fízole que le diese la pescozada en el carriello" ${ }^{\prime 40}$. Y efecti-

39 Carrero Santamaría, "The Libro de la Coronación...". También Rodríguez Porto, "Mística regia y ambiciones compostelanas...".

${ }^{40}$ Cayetano Rosell, ed., Crónicas de los Reyes de Castilla (Madrid: Biblioteca de Autores Españoles, Rivadeneyra Editor, 1817-1883), vol. I, 234. Linehan, At the Edge of Reformation..., 70-71. Linehan, además, se permite reproducir el fragmento de un correo electrónico privado cruzado entre él y yo en diciembre de 2012. Le repetía mi opinión sobre las tardías fechas de transformación de la imagen, en virtud de la cronología de las manos vamente aquí está el nudo gordiano de todo el asunto. ¿A qué imagen se está refiriendo la crónica? ¿La pescozada recibida por el rey es una realidad física o, por el contrario, forma parte del imaginario simbólico medieval relativo a las imágenes? Vayamos por partes.

En 1998, Nelly R. Porro Girardi ya apuntó al talón de Aquiles de la consideración de la imagen burgalesa como autora del espaldarazo. Como indica la autora respecto a la disposición física de la pieza, un dato interesante es que la figura tiene una espada en la mano para dar el golpe que sustituyó a la pescozada. Según vimos, esta se daba con la mano y no con la espada, uso que se comenzó a practicar a partir del reinado de Pedro I de Castilla, aunque no de forma generalizada según ponen de manifiesto crónicas como la de Fernando de Antequera, en la que se subraya que el mismo rey se dio la pescozada con su mano y no con espada alguna ${ }^{41}$. Para solucionar el problema y a sabiendas de este importante dato, María José Martínez ha traído a colación la descripción de la toma de armas en las Partidas alfonsíes, en las que se indica cómo al armar caballero, el rey debía tener la espada desenvainada en una mano, mientras con al otra daba la pescozada: "Et desque el espada le hobiere ceñida, débela sacar de la vayna et ponérgela en la mano diestra, et facerle jurar (...) et quando esto hobiere jurado débele dar una pescozada" ${ }^{42}$. En su opinión, la mano izquierda de la figura está abierta para dar la pescozada, hecho que además justifica las articulaciones de esta. Es decir que, la figura era una monumental marioneta guiada por los hilos, una cruceta o por algún otro dispositivo manejado, no por una tercera persona implicada en

y la espada de la imagen. En ningún momento explica que el mensaje era la respuesta a un primero, en el que me espetaba que la figura se tuvo que transformar antes de 1332 para que casara cronológicamente con su interpretación.

${ }^{41}$ Porro Girardi, La investidura de armas en Castilla..., $165-167$ y 287.

${ }^{42}$ Las siete partidas del rey don Alfonso el Sabio, cotejadas con varios códices antiguos por la Real Academia de la Historia (Madrid: Imprenta Real, 1807), T. II, 209. 
el rito, sino por el propio rey, que habría accionado la imagen a través de un mecanismo de cordones ${ }^{43}$. Ya hemos visto que no existe el menor rastro de un dispositivo semejante. Más comedido fue Bonifacio Palacios, que sólo planteó que el rey acercaría la cara a la imagen, a pesar de seguir afirmando que el viaje hasta Compostela fue con el fin de encontrarse con la figura articulada ${ }^{44}$.

Una monarquía con una tradición propia por la que se auto coronaba, se proclamaba, se auto investía caballero tomando las armas del altar, ahora metía de por medio la imagen que el propio rey convertido en titiritero accionaba para refrendar su paso a la caballería de mano de un Apóstol de madera, en la catedral de Santiago. La figura que, por otra parte, no se conserva en Compostela sino en Las Huelgas de Burgos, donde se la documenta por primera vez en el siglo XVII. Además, siguiendo las restauraciones, no es más que un contrafactum -contrahechura en el léxico musical- de una imagen previa de la Virgen, a la que se dotó de unos brazos articulados, una espada y una barba de estopa para convertirla en un santo de vestir, en una fecha que las huellas dejadas por la transformación llevan a décadas muy posteriores al año 1332, cuando el rey Alfonso tomó las armas en Compostela. ¿No es mucho más fácil $\mathrm{y}$, sobre todo, lógico suponer que la frase de la crónica real, argumentada como prueba irrefutable de una imagen que hiciera al Apóstol padrino de la ceremonia, se está refiriendo en realidad a la figura del altar mayor de la catedral de Santiago y que la recepción de su pescozada fue, simplemente, simbólica? En una época cuajada de aspectos alegóricos y en una ceremonia marcada precisamente por su constante carácter simbólico, que el cronista afirmara que el rey recibió la caballería del Apóstol no puede pasar más que de eso, de una retórica emblemática en la que efectivamente, el monarca recibía la pescozada de la divinidad y no de

\footnotetext{
43 Martínez Martínez, "Las imágenes articuladas...", 264-265.

${ }^{44}$ Palacios Martín, "Investidura...".
}

manos humanas. Tampoco de un turbador muñeco hecho de retales y manejado por un operario. Varias cuestiones refrendan nuestra hipótesis. En primer lugar, el Libro de la Coronación de los Reyes de Castilla -que es utilizado cuando conviene como vademécum de la liturgia regia de Alfonso XI y que reúne las dos ceremonias de toma de armas y coronación- ni siquiera plantea la pescozada ni, por supuesto, alude a imagen intermediaria alguna. El rey se ciñe la espada y este es el acto básico y no pescozada alguna ya sea con la mano, ya con una espada: "Et por sennal desto, el día de la sagraçión le deuen cennir la espada cerca de los lombos e después deue la poner en la mano a dar a entender que por el çennir de la espada se deue restrenner de las uoluntades carnales e por la poner en la mano toma fortaleza de buenas obras" ${ }^{\prime 4}$.

Por otra parte, la representación del altar mayor de Santiago ante el que se escenifica el rito en el propio Libro muestra a la comitiva arzobispal dirigiéndose hacia los reyes y cortesanos a ambos lados del altar sobre el que se halla la figura en pie del Apóstol (Fig. 8). En esta no hay intención alguna de representar una figura sedente con espada en ristre y lista para dar pescozadas a reyes. Un elemento tan singular que debiera haber sido recogido en imagen y texto. Por el contrario, se trata de la imagen de Santiago que desde el siglo XIII preside el altar mayor compostelano (Fig. 9), con un libro -en lugar de filacteria- en una mano, sosteniendo el bordón en la otra, cubierto con sombrero y con la escarcela colgada. La prototípica iconografía de Santiago peregrino. ¿Por qué no fue representado en el Libro de la Coronación? Si su papel hubiera sido tan relevante como para conferir la voluntad divina al rey por delante de autoridades eclesiásticas, más noticias habrían llegado sobre la figura. Habría, al fin y al cabo, más cultura literaria e incluso visual sobre esta.

Y es que la figura del altar mayor compostelano tenía la suficiente entidad cultual

97. 


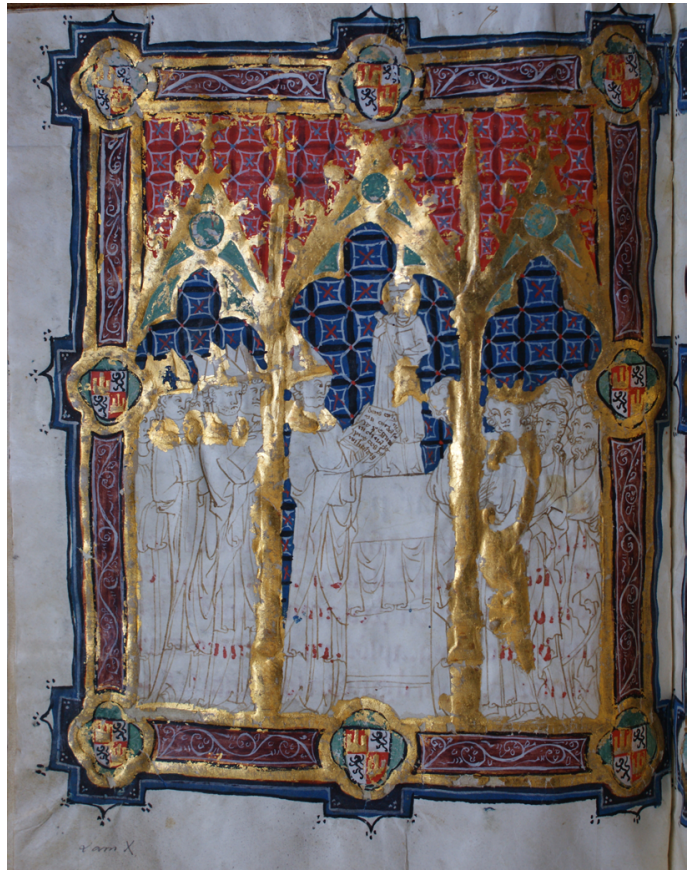

- Fig. 8. Imagen del altar mayor de la Catedral de Santiago en el Libro de la Coronación de los Reyes de Castilla (Real Biblioteca de San Lorenzo del Escorial). Foto: Ediciones Escurialenses.

y material como para convertirse en la que simbólicamente diera el espaldarazo al rey. Tanta parafernalia para que, al fin y a la postre, no fuera más que una mano humana la que pudiera mover la imagen. Muchas imágenes medievales tuvieron todo un elenco de atribuciones milagrosas y pararreligiosas que son detenidamente relatadas en textos piadosos, en libros educativos para novicios, en tradiciones locales en las que imágenes -básicamente de la Virgen y del Crucificado- $y$, movidas por las acciones de quienes a ellas se acercaban, hablaron, sangraron, lloraron, cobijaron a sus devotos, se protegieron de ladrones y blasfemos e, incluso, abrazaron a sus fieles ${ }^{46}$. Hay algún caso en

46 Véase el trabajo clásico de André Vauchez, “L'image vivante: quelques réflexions sur les fonctions des représentations iconographiques dans le domaine religieux en Occident aux derniers siècles du Moyen Âge", en Pauvres et riches. Société et culture du Moyen-Âge aux Temps Modernes. Mélanges offerts à Bronislaw Geremek à l'occasion de son sixantième anniversaire (Varsovie: Wydawn. Naukone PWN, 1992), 231-240, reed. en “Les images saintes: représentations iconographiques et manifestations du sacré", en André Vauchez, Saints, pro-

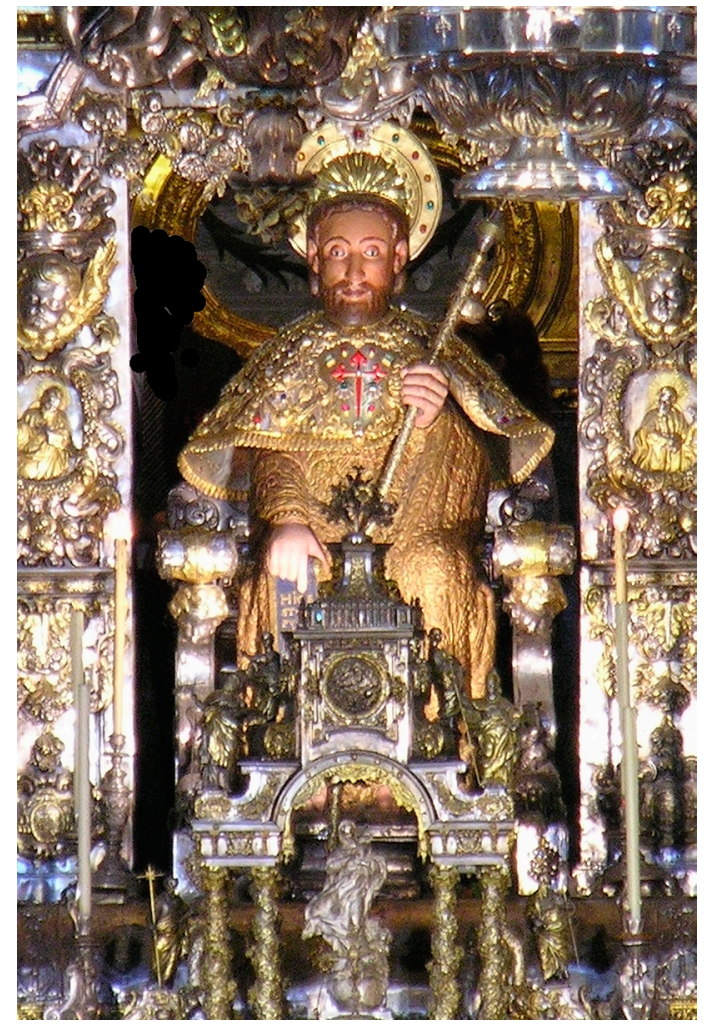

- Fig. 9. Imagen del altar mayor. Catedral de Santiago de Compostela. Foto del autor.

el que la imagen contó con un dispositivo que la hiciera activar tanto el milagro como el fraude. No es este el caso que nos interesa. La catedral de Santiago y el cuerpo santo del Apóstol jugaron un papel fundamental en el programa hagiográfico de la monarquía castellana. Resulta absurdo que, en el marco de la catedral y teniendo como escenario el altar mayor-relicario y la figura alrededor de la cual se montó la paraliturgia de abrazo

phètes et visionnaires. Le pouvoir surnaturel au Moyen Âge (Paris: Albin Michel, 1999), 79-91 y 240-242. Ahora, ampliando el asunto, Jean-Marie Sansterre, "La imagen activada por su prototipo celestial: milagros occidentales anteriores a mediados del siglo XIII", Codex Aquilarensis, 29 (2013), 77-98. El contexto alfonsí en Alejandro García Avilés, "Imágenes 'vivientes': Idolatría y herejia en las Cantigas de Alfonso X el Sabio", Goya, 321 (2007), 324342 y "'Este rey tenno que enos idolos cree': imágenes milagrosas en las Cantigas de Santa María", en Alfonso X El Sabio 1221-1284. Las Cantigas de Santa María, vol. II: Códice Rico, Ms. T-I-1 Real Biblioteca del Monasterio de San Lorenzo de El Escorial, Estudios, ed. por Laura Fernández Fernández y Juan Carlos Ruiz Souza (Madrid: Testimonio Compañía Editorial, 2011), 523-559. 


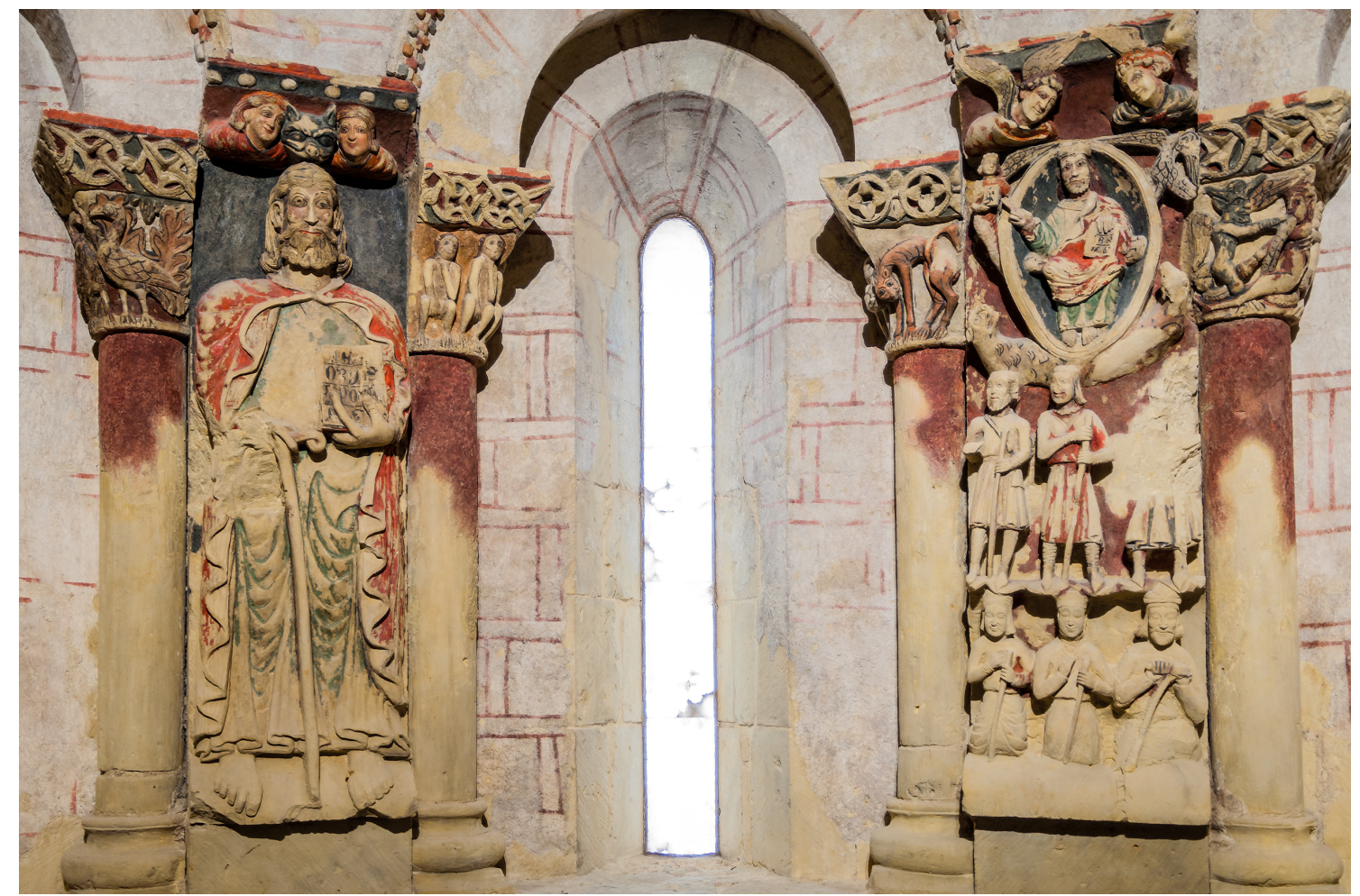

- Fig. 10. Representación de la imagen de Santiago en la catedral de Compostela. Iglesia de Santiago de Turégano (Segovia). Foto: Diego Conte Bragado.

a Santiago, aun así, tuviera que construirse una figura apostólica a partir de una pieza previa y que creara una extraña duplicidad de imágenes del Patrón presidiendo el mismo altar mayor de la catedral. Después, la imagen sería trasladada hasta el monasterio de Las Huelgas de Burgos, donde su indocumentada pero presupuesta participación en las ceremonias reales que se sucedieron entre sus muros ha pasado al fecundo catálogo imaginario de la historiografía al uso.

En referencia a la planteada duplicidad icónica del Apóstol para la toma de armas de Alfonso XI, la imagen de Santiago en la capilla mayor de la catedral compostelana ejerció una fascinación singular entre los fieles (Fig. 9). A comienzos del siglo XIII se situó sobre el muro que separaba la capilla mayor de la retrocapilla de la Magdalena, en donde se celebraban las misas matinales para los peregrinos. La figura recibía un culto especial y era objeto de la paraliturgia en la que participaban los peregrinos dándole el célebre abrazo y, los alemanes, la ceremonia del sombrero que generó su propia iconografía ${ }^{47}$. Como decía, la figura tuvo un importante impacto sobre su medio cercano. La devoción a su alrededor llevó a que se le rindiera culto en lugares cercanos y lejanos, llegándose a copiarla como objeto de culto. Así, en fechas inmediatas a su colocación en el presbiterio de la catedral, una escultura en granito conservada en el Museo de la Catedral y datada hacia 1250 muestra las variaciones que la iconografía del Santiago en cátedra del parteluz del Pórtico de la Gloria y la del Santiago peregrino estaban produciendo. Se generaban imágenes sincréticas de ambas figuras pero que insistían en su importancia devocional ${ }^{48}$. En las mismas fechas y en la iglesia parroquial que se le dedicaba al Apóstol en la villa segoviana de Turégano se esculpieron dos relieves colocados en la capilla mayor, reproduciendo la imagen del

${ }^{47}$ Robert Plötz, "Santiago Coronatio Peregrinorum", en Santiago, camino de Europa..., 344, recogiendo los estudios de referencia.

${ }^{48}$ Serafín Moralejo, "Estatua sedente de Santiago coronado", en Santiago, camino de Europa..., 343. 
Apóstol de la catedral y a los peregrinos que hasta ella se acercaban ${ }^{49}$ (Fig. 10). Y su fama no decayó hasta fechas muy tardías. Como bien indica el célebre frontispicio del cartulario del Hospital de Santiago de Tournai ${ }^{50}$, a finales del siglo XV las paraliturgias de peregrinos alrededor de la imagen eran igualmente populares y se desarrollaban en plena forma (Fig. 11) $)^{51}$.

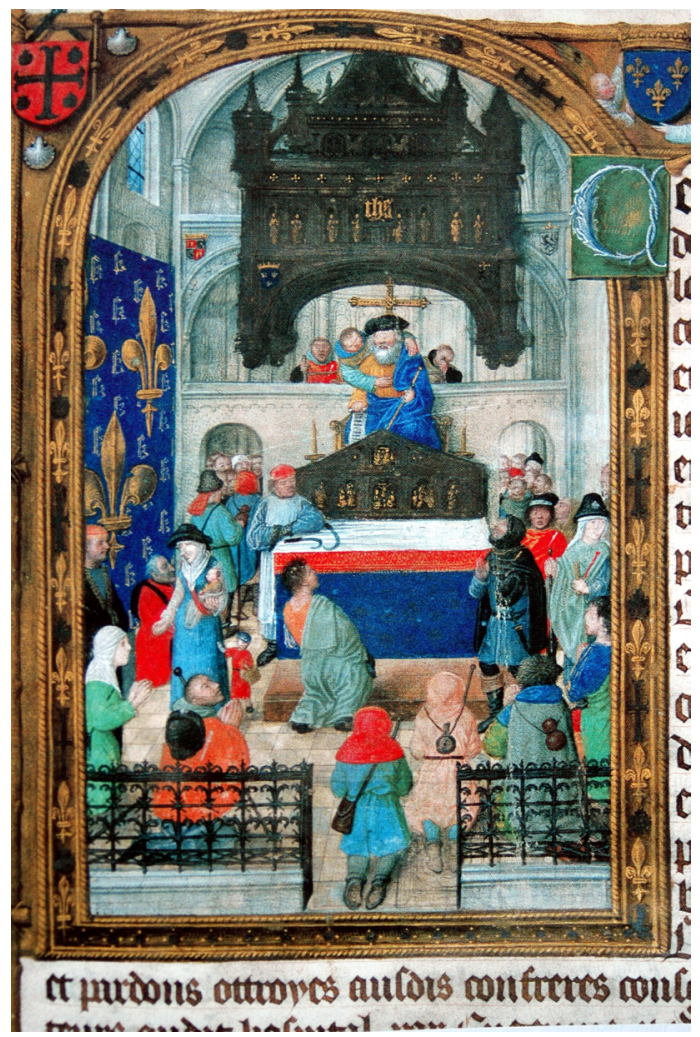

- Fig. 11. Cartulario del Hospital de Saint-Jacques de Tournai (Tournai, Bibliothéque de Ville). Foto: Tournai, Bibliothéque de Ville.

${ }^{49}$ Manuel Castiñeiras, “Un nuevo testimonio de la iconografía jacobea: Los relieves pintados de Santiago de Turégano (Segovia) y su relación con el altar mayor de la Catedral de Santiago", Ad Limina, 3 (2012), 73-117.

${ }^{50}$ Tournai, Bibliothèque de la Ville, ms.27.

${ }^{51}$ Dominique Vanwijnsberghe, "Réalité et fiction chez le Maître du Livre d'Heures de Dresde. Le frontispice du Cartulaire de l'Hôpital Saint-Jacques de Tournai (Tournai, Bibliothèque de la Ville, ms. 27)", en 'Als Ich Can'. Liber Amicorum in Memory of Professor Dr. Maurits Smeyers, ed. por Bert Cardon, Jan Van der Stock y Dominique Vanwijnsberghe (Leuven: Peeters Publishers, 2002), vol. II, 1509-1546.
Por fin y relacionada con la imagen de Las Huelgas y su singular iconografía jacobea, no se había traído a colación la imagen pétrea de Santiago, que presidió un altar menor en la cabecera de la catedral de Orense, allí documentado desde el siglo XV. En 1857 se trasladó al parteluz del pórtico occidental, que en la actualidad preside, pero nos interesa porque, si en su mano izquierda nos muestra un libro abierto, en la derecha que apoya en el regazo en tiempos modernos se le practicó un agujero para colocar una espada metálica (Fig. 12). El hierro se registra por primera vez en un pago de $1782 \mathrm{y}$, con certeza, alude al instrumento del martirio del Apóstol, como requerían las normativas postridentinas ${ }^{52}$. Otra imagen apostólica transformada y dotada de una espada sin relación alguna con ritos caballerescos ni regios.

La teoría de la imagen durante la Baja Edad Media europea nos inclina a ser cautos. El entorno monástico fue dado al uso de imágenes en las festividades propias de la comunidad. Imágenes móviles no en tanto que cambiaran de postura, como aquí se propone, sino figuras que podían trasladarse de un lugar a otro. Sin salir de Las Huelgas, y en el mismo contexto regio, Josemi Lorenzo nos recuerda el apasionante testimonio de una de las Cantigas de Santa María, la 361, en la que nuestras monjas actuaron teatralmente como parteras de la Virgen. Se trataba de una imagen especial, donada por Alfonso $\mathrm{X}$ a las monjas y que "come se fosse carnal (...) demais era tan ben feita e de tan omil fayçon", atendía las plegarias de la comuni$\mathrm{dad}^{53}$. La preciosa cantiga narra las liturgias

${ }^{52}$ Miguel Ángel González García, “Representación de Santiago en la catedral de Ourense", Faro de Vigo, 27 de octubre de 2013 y Eduardo Carrero Santamaría, "Compostela, pauta y evocación en el Pórtico del Paraíso de la catedral de Ourense", en Modelo, copia y evocación en el Románico hispano (Aguilar de Campóo: Fundación Santa María la Real, 2016), 82-109.

${ }^{53}$ Josemi Lorenzo Arribas, “La música en el monasterio de Las Huelgas en tiempos de su códice polifónico", en El códice de Las Huelgas, ed. por Juan Carlos Asensio Palacios (Madrid, Alpuerto, 2001), 21-36. 


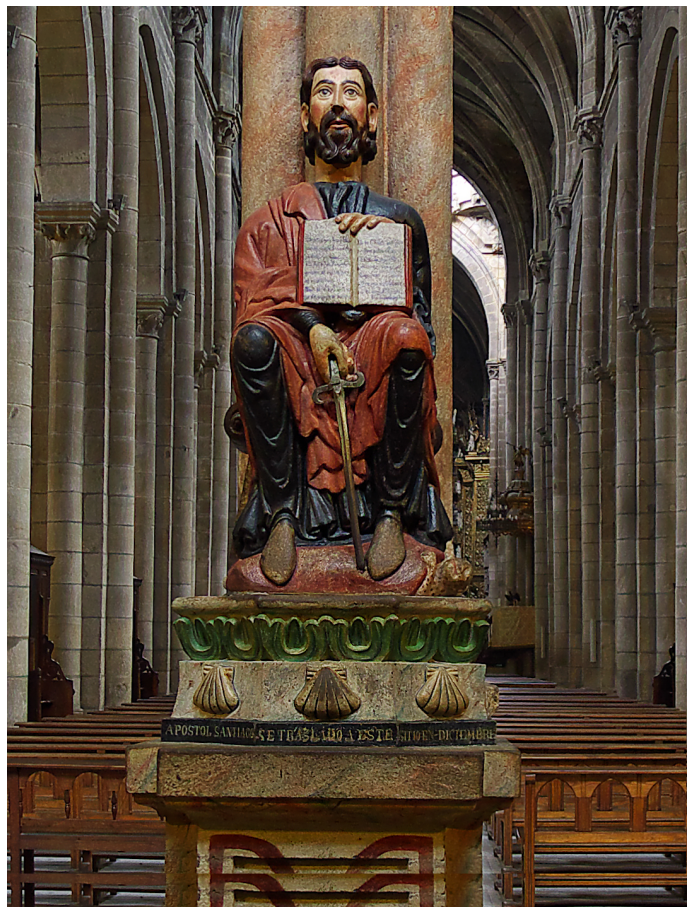

- Fig. 12. Imagen de Santiago en el parteluz del Pórtico del Paraíso. Catedral de Orense. Foto del autor.

teatralizadas de las monjas que, en la noche de Navidad, hacían una gran fiesta, componiendo una cama en la que situar a la imagen para que pariera al Niño Jesús, rodeada por sus cantos. Milagrosamente, la imagen gesticuló durante el parto: “Ond'avẽo ena noite de Navidad', en que faz / Santa Igreja gran fésta, que as monjas por solaz / fezéron mui rico leito, e come mollér que jaz / deitaron i a imagen e fezéron-na jazer. / Come mollér que parira. E as monjas arredor / do leito pousaron todas, e seend'a gran sabor / catand'aquela omagen, viron-lle mudar coor / na face e dũu lado ao outro revolver" ${ }^{\prime 2}$.

Pero no es el milagro lo que nos interesa aquí, sino el aparato escénico. ¿Hay una imagen de la Virgen de parto que, al modo de un dummie automovilístico, fuera usada en esta ceremonia paralitúrgica? No lo parece. El imaginario medieval es infinitamente más fecundo. La historiografía ha tendido a pensar que toda imagen tenía la posibilidad de ser articulada. No voy a entrar aquí en el

${ }^{54}$ Alfonso X, Cantigas de Santa María, ed. por Walter Mettmann (Madrid: Castalia, 1988-2004), vol. III, 233. conflicto que representa la revisión de las consideradas imágenes móviles anteriores al siglo XVI, al que ya nos referimos en páginas previas, pero de lo que sí quisiera dejar constancia es de que fue el hecho milagroso el que acabó por generar una imagen y que piezas como el Cristo de la Vega de Toledo no eran articuladas, pero sí fueron después reinterpretadas en la acción que les atribuía el hecho milagroso, en este caso, con un brazo descolgado. Lo mismo ocurre con los grupos del Descendimiento. Como parte del propio grupo, la imagen de Cristo no estaba articulada, eran conjuntos inseparables que escenificaban un hecho de la historia sagrada. Fue en fechas muy tardías cuando alguno de sus descendidos fue alterado añadiéndole articulaciones. No parece que la Virgen de Las Huelgas pariera, ni que a modo de un ventrílocuo gesticulara o que las articulaciones del Santiago del Espaldarazo fueran activadas para dar cachetes caballerescos.

Regresando finalmente a la iconografía jacobea, la figura carece de cualquier otro elemento iconográfico que la identifique con Santiago. La espada que sostiene es una suerte de daga corta y plana que nada tiene que ver con las propias del siglo XIV. Para los más escépticos, efectivamente, la espada podría haber sido repuesta en tiempos modernos. Otra cosa sería plantearnos para qué fue repuesta, cuando la pieza ya no se usaba, pero eso es otra cuestión que dejamos para el final. En cualquier caso, el hecho de portar una espada podría emparentar a la imagen con la conocida iconografía de Santiago caballero y, aún más, con otras ceremonias de caballerías como aquélla por la que Fernando el Católico armó a Gonzalo de Herrera con la apostilla "Dios nuestro Señor y el Apóstol Santiago te fagan buen caballero" ${ }^{55}$. Siento recordar aquí que, si el testimonio ya es de finales del siglo XV, la iconografía de Santiago caballero y su carácter simbólico recorren toda la Edad Media peninsular sin ser garante de nada.

${ }^{55}$ Citado por Porro Girardi, La investidura de armas en Castilla..., 166. 


\section{RECAPITULANDO. TRES SOLUCIO- NES POSIBLES PARA EL SANTIAGO DEL ESPALDARAZO}

Visto lo visto, no parece haber una solución fácil para la imagen custodiada en Las Huelgas. Aún así, intentaremos barajar posibles respuestas al enigma. La primera pasa por considerar que, efectivamente, la escultura se alteró para ser utilizada en el ceremonial regio, aunque, como demuestra la cronología de su transformación, no para el de Alfonso XI. Sin duda, la talla no es una forgery, lo que no es certera es la interpretación que de ella se hace. Sólo Alfonso XI se armó caballero en Santiago. El resto de sus sucesores lo hicieron en Las Huelgas. Siguiendo este elenco de suposiciones y factores dados por hecho, ¿pudo -como ya propuso Rocío Sánchez Ameijeiras- haber sido hecha para Las Huelgas, siendo la sustituta de la imagen catedralicia real, la de la capilla mayor compostelana, que dio el simbólico espaldarazo al rey en 1332? Las articulaciones vendrían de la propia transformación y de su tipo vestidero, destinada a engalanarla durante los festejos. En cierto modo, esto evitaría la historia-ficción de la imagen transformada por voluntad real viajando de un centro religioso a otro $y$, sobre todo, el espectáculo de convertirla en títere móvil para una ceremonia real en el altar mayor de una catedral.

La segunda hipótesis es que, si las articulaciones y extremidades que se le añadieron recomiendan unas fechas tardías para su conversión, podríamos aventurar que la imagen tuviera algo que ver con las voluntades de canonización de Alfonso VIII. Según nos relata Amancio Rodríguez López, durante el abadiato de Ana de Austria se documentan toda una serie de prodigios alrededor del sepulcro del rey fundador, situado en la nave de la iglesia. Junto a otros testimonios, los fenómenos comenzaron a ser recogidos en 1624 por solicitud de Felipe III, para ser enviados a la Santa Sede con el fin de incoar un expediente de canonización del rey castellano, intención que parece pudiera

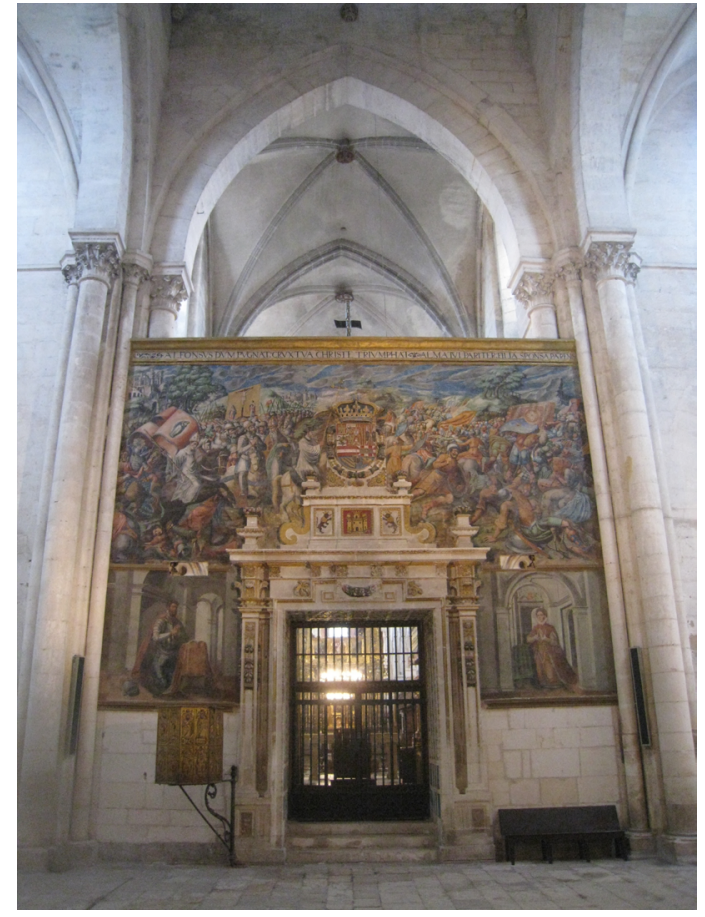

- Fig. 13. Vista del cierre de coro del transepto desde la capilla mayor. Monasterio de Santa María la Real de Las Huelgas de Burgos. Foto del autor.

retrotraerse al reinado de Felipe II sólo unas décadas antes. Las pesquisas llegaron hasta la apertura del sepulcro real en el que, según Baltasar Porreño, se encontró "el cuerpo entero, sentado en una silla real, sobre una almoada de olanda blanca, tan nueva como quando se hizo y sus ropas enteras y sanas y recias" ${ }^{\prime \prime 6}$. Incluso se le llegaron a atribuir milagros, como el cese del temporal que afectó a la comitiva del rey Felipe III de camino a Las Huelgas en 1615. Después de que doña Ana de Austria pusiera a arder un cirio junto al sepulcro del fundador, la tormenta

\footnotetext{
${ }^{56}$ Baltasar Porreño, Historia del Santo Rey don Alonso el Bueno. Alfonso VIII, ed. por Miguel Salas Parrilla (Cuenca: Diputación Provincial, 2018). Recoge la noticia Beatriz Mariscal, "Historia y leyenda en el teatro de Lope de Vega, Las paces de los reyes y judía de Toledo", en Tiempo e historia en el teatro del Siglo de Oro, dir. por Isabelle Rouane Soupault y Philippe Meunier (Aix-en-Provence: Presses Universitaires de Provence, 2015), enlace web. Un contexto para la operación de canonizar al rey a comienzos del siglo XVII en Inmaculada Rodríguez, "Los reyes santos", en Visiones de la monarquía hispánica, ed. por Víctor Mínguez (Castellón de la Plana: Universitat Jaume I, 2007), 133-170.
} 


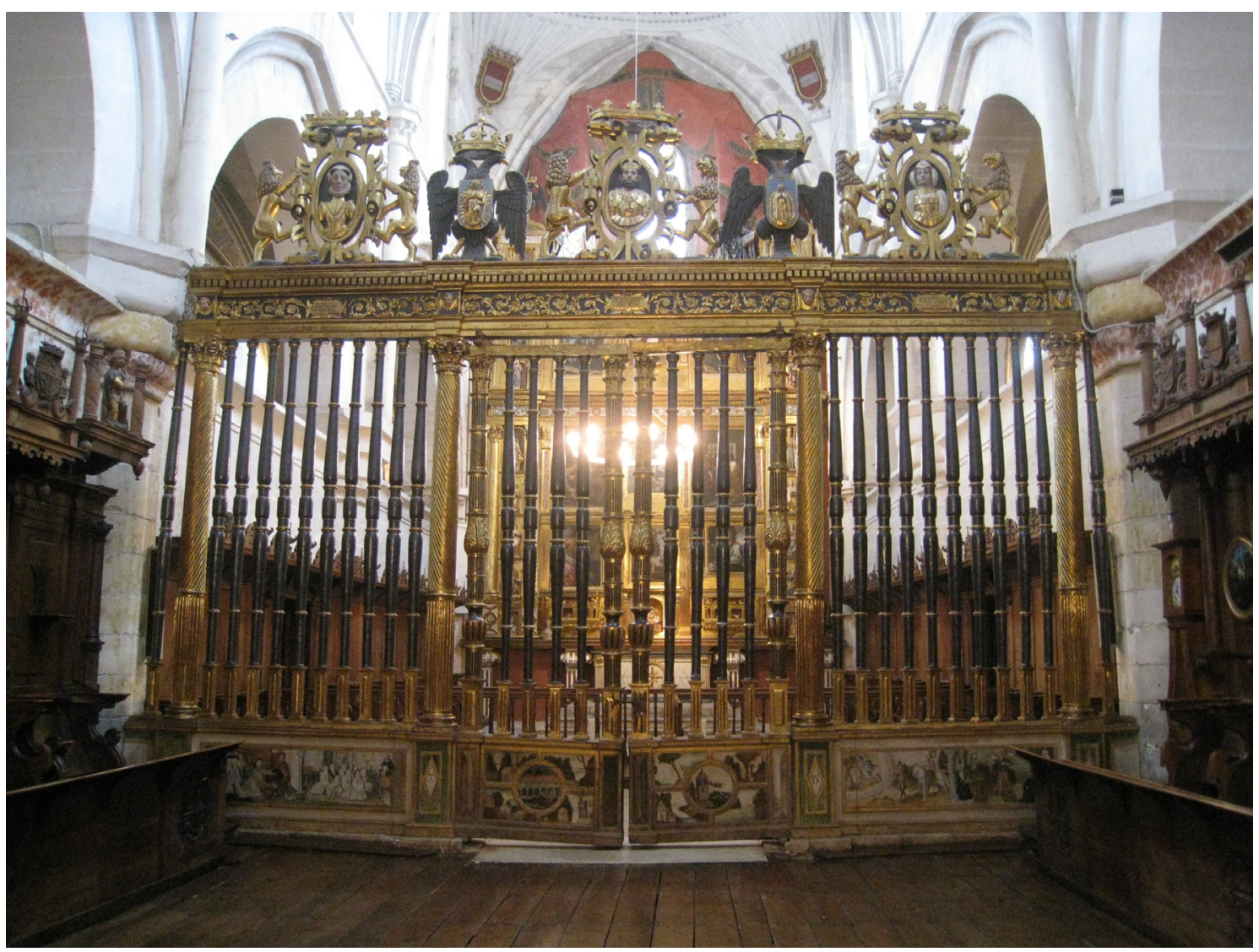

- Fig. 14. Reja de separación entre el coro de las monjas y el coro de las conversas. Monasterio de Santa María la Real de Las Huelgas de Burgos. Foto del autor.

cesó... ${ }^{57}$. En el momento se realizaron en la iglesia abacial las pinturas dedicadas al ven-

\footnotetext{
${ }^{57}$ Rodríguez López, El Real Monasterio de Las Huelgas..., vol. II, 134-135. Una copia del expediente recogiendo los milagros realizados por intercesión del rey puede consultarse en el Archivo Histórico Nacional (AHN), en Madrid: Compendio de las informaciones, compulsas de historias, etc. acerca de la vida y santidad de Alfonso VIII de Castilla y Toledo, fundador del Monasterio bernardo de La Asunción (Las Huelgas) y del Hospital del Rey de Burgos, para su beatificación y canonización, iniciado en el año 1624, Códices, L.771. En ningún caso la pretendida canonización de Alfonso VIII puede llevarse más atrás en el tiempo, según se desprende de Amaia Arizaleta y Stéphanie Jean-Marie, "En el umbral de santidad. Alfonso VIII de Castilla", en Pratiques hagiographiques dans l'Espagne du Moyen Âge et $d u$ Siècle d'Or, coord. por Amaia Arizaleta (Toulouse: Université de Toulouse-Le Mirail, 2005), vol. II, 573-583. Sobre el recuerdo de Alfonso VIII en Las Huelgas, véase Raquel Alonso Álvarez, “La memoria de Alfonso VIII de Castilla en las Huelgas. Arquitectura y liturgia funeraria", en 1212, un año, un reinado, un tiempo de despegue. XXIII Semana de Estudios Medievales, Nájera 2012, coord. por Esther López Ojeda (Nájera: Instituto de Estudios Riojanos, 2013), 349-376.
}

cedor de Las Navas que, junto a su retrato y el de su esposa y a modo de un proscenio, enmarcan la vista del sepulcro real desde la reja del transepto, el lugar al que los fieles tenían libre acceso (Fig. 13). También se decoraron las rejas que separan los coros de monjas y hermanas conversas con escenas de los milagros que se le atribuyeron al rey, rematadas por las efigies reales de Carlos I, Felipe II, Juan de Austria, doña Berenguela, Felipe III y, claro, Alfonso VIII (Fig. 14) ${ }^{58}$.

Por último y de la mano de su interpretación en el contexto del intento de canonización de Alfonso VIII, ¿sería demasiado descabellado pensar que el destino de la transformada imagen fuera el de pieza de atrezo

${ }^{58}$ René Jesús Payo Hernanz, El retablo en Burgos y su comarca durante los siglos XVII y XVIII (Burgos: Publicaciones de la Excma. Diputación de Burgos, 1997), vol. I, $464 \mathrm{y}$ El arte de la madera en Burgos durante los siglos XVII y XVIII (Burgos: Aldecoa, 1997), 139-143. 
en las paraliturgias de las propias monjas? El proceso sufrido por la talla no es ni mucho menos único. Un importante número de imágenes medievales fueron convertidas en fechas modernas en figuras vestideras, incluso variando su identidad y su género. La cabeza o el rostro de una figura podía ser usado retallándose la estructura del cuerpo y quedando como santo de vestir que podía hasta cambiar de advocación ${ }^{59}$. Como vimos en el apartado dedicado a la restauración, nuestro Santiago del Espaldarazo pudo llevar una corona que explicara las huellas que tiene en la cabeza. Por otro lado, como bien sabemos, la compleja vida litúrgica de un monasterio femenino conllevaba ceremonias propias, representaciones teatrales, juegos casi de corte en el que las dueñas se declaraban devotas de tal o cual santo al que, divididas en grupos y en una suerte de justas poéticas, le dedicaban los versos más cumplidos, en ocasiones reunidas alrededor de su imagen ${ }^{60}$. Del mismo modo, el recuerdo del rey Alfonso VIII como fundador de una casa religiosa de claro sesgo nobiliario pudiera haber pasado por ser objeto de alguna paraliturgia en la que la figura de la Virgen transformada en Apóstol Santiago tuviera algo que ver. El modelo de personaje coronado, portando una espada, con la mano apoyada en el regazo nos remite directamente a las series icónicas de la monarquía castellana, como la del Alcázar de Segovia, donde todos los reyes aparecen en posición seme-

${ }^{59}$ Por ejemplo, la Virgen María articulada de La Spezia, que hasta finales del XVI fue una santa Lucía, cf. Piero Donati, "Santa Lucia, 1450-1470 circa", en La Sacra Selva. Scultura lignea in Liguria tra XII e XVI secolo, ed. por Franco Boggero y Piero Donati (Ginebra-Milán: Skira, 2004), 180-181.

${ }^{60}$ El trabajo de contexto es el de Pedro M. Cátedra, Liturgia, poesía y teatro en la Edad Media (Madrid: Gredos, 2005). También Elissa B. Weaver, Convent Theatre in Early Modern Italy. Spiritual Fun and Learning for Women (Cambridge: Cambridge University Press, 2002) $\mathrm{y}$ "Convent Education and the Role of Theater, 15001650", en Scritture, Carismi Instituzioni. Percorsi di vita religiosa in età moderna. Studi per Gabriella Zarri, ed. por Concetta Bianca y Anna Scatigno (Roma: Edizione di Storia e Letteratura, 2018), 499-512.

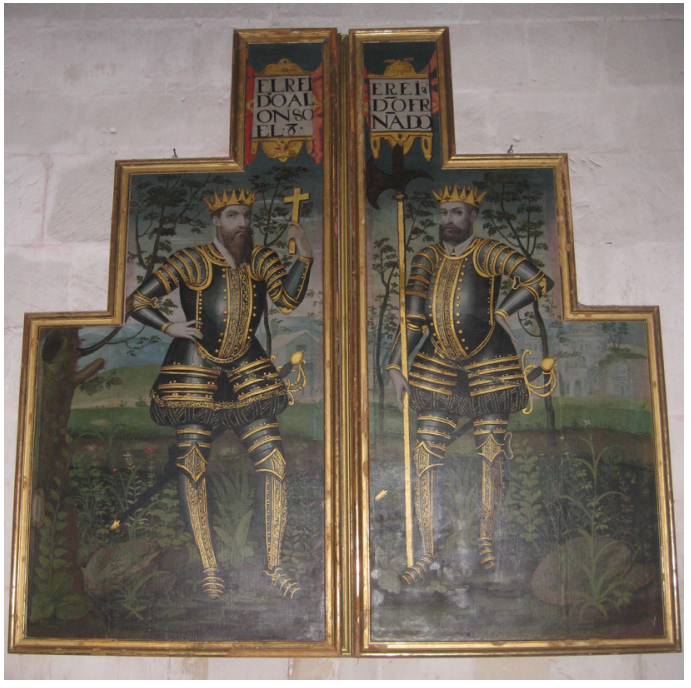

- Fig. 15. Anverso de las puertas del órgano de comienzos del siglo XVII. Monasterio de Santa María la Real de Las Huelgas de Burgos. Foto del autor.

jante, sólo variando de atavío ${ }^{61}$. ¿Motivada, como decíamos, por el incoado proceso de canonización real o, tal vez, por la sanción papal a la monarquía castellana con la canonización -esta vez sí- de Fernando III en 1671? En tal caso no sería una obra única. El recuerdo de ambos reyes se recogió en el interesante conjunto pictórico de las puertas del órgano del monasterio, hoy conservadas (Fig. 15). En cualquier caso, no nos engañemos. Al igual que las restantes posibilidades, esta no es más que otra suposición. Con toda sinceridad y para tranquilidad de beligerantes historiadores defensores de la tradición o de imposturas intelectuales, si la talla fue usada o no para armar caballero a Alfonso XI o a cualquier otro rey no tiene relevancia alguna en la teoría de estado de la monarquía castellana. Sólo es una cuestión de atrezo.

\footnotetext{
${ }^{61}$ Aunque ardiera en el incendio de 1862, las fuentes iconográficas previas son claras al respecto, cf. Marta Virseda, "La Galería de los Reyes del Alcázar de Segovia: una revisión historiográfica", en Perspectivas actuales horizontes insólitos. Dinámicas y aportaciones teóricas en Historia del arte, ed. por Helena Carvajal et al. (Logroño: Aguja de Palacio Ediciones, 2017), 37-62.
} 


\section{BIBLIOGRAFÍA}

Agapito y Revilla, Juan. El Real Monasterio de las Huelgas de Burgos. Apuntes para un estudio histórico-artístico. Valladolid: La Nueva Pincia, 1903.

Alfonso X. Cantigas de Santa María. Editado por Walter Mettmann. Madrid: Castalia, 1988-2004.

Alonso Abad, Pilar. El Real monasterio de Las Huelgas. Historia y arte. Burgos: Patrimonio Nacional-Caja Círculo, 2007.

Amador de los Ríos, Rodrigo. España. Sus monumentos y artes, su naturaleza e historia Burgos. Burgos-Barcelona: Establecimiento tipográfico de Daniel Cortezo y Cía, 1888.

Alonso Álvarez, Raquel. “La memoria de Alfonso VIII de Castilla en las Huelgas. Arquitectura y liturgia funeraria". En 1212, un año, un reinado, un tiempo de despegue. XXIII Semana de Estudios Medievales, Nájera 2012, coordinado por Esther López Ojeda, 349-376. Nájera: Instituto de Estudios Riojanos, 2013.

Arizaleta, Amaya y Stéphanie Jean-Marie, Jean-Marie. "En el umbral de santidad. Alfonso VIII de Castilla". En Pratiques hagiographiques dans l'Espagne du Moyen Âge et du Siècle d'Or, coordinado por Amaya Arizaleta, vol. 2, 573-583. Toulouse: Université de Toulouse-Le Mirail, 2005.

Arquillo Torres, Joaquín. "Aspectos socio-religiosos en la conservación de las representaciones escultóricas marianas. Influencia en tres imágenes representativas". Tesis doctoral. Universidad de Sevilla, 1989.

Assas, Manuel de. "Sepulcro de la reina doña Berenguela en el monasterio de Las Huelgas junto a Burgos y noticias históricas y artísticas con motivo de esta monografía acerca de aquel célebre monasterio". Museo Español de Antigüedades, IV (1875), 126-158.
Azcárate Ristori, José María de. "La capilla de Santiago en Las Huelgas de Burgos". Reales Sitios, 28 (1971), 49-52.

Carrero Santamaría, Eduardo. “Observaciones sobre la topografía sacra y cementerial de Santa María la Real de las Huelgas, en Burgos, y su materialización arquitectónica". En La clausura femenina en España. Actas del Simposium, vol. II, 695715. San Lorenzo del Escorial: Instituto Escurialense de Investigaciones Históricas y Artísticas, 2004.

Carrero Santamaría, Eduardo. "Architecture and Liturgical Space in the Cathedral of Santiago de Compostela. The Libro de la Coronación de los Reyes de Castilla". Hispanic Research Journal, 13 (2012), 466-486.

Carrero Santamaría, Eduardo. "Por Las Huelgas los juglares. Alfonso XI de Compostela a Burgos siguiendo el Libro de la coronación de los reyes de Castilla". Medievalia. Revista d'estudis medievals, 15 (2012), 143157.

Carrero Santamaría, Eduardo. "The Creation and use of space in the Abbey of Santa María la Real de Las Huelgas, Burgos: architecture, liturgy, and paraliturgy in a female Cistercian monastery". Journal of Medieval Iberian Studies, 29 (2014), 1-23.

Carrero Santamaría, Eduardo. “Epigrafía y liturgia estacional entre el locutorio y el pasaje a la enfermería de la abadía de Santa María la Real de las Huelgas, en Burgos". Territorio, Sociedad y Poder, 9 (2014), 117-132.

Carrero Santamaría, Eduardo. “Compostela, pauta y evocación en el Pórtico del Paraíso de la catedral de Ourense". En Modelo, copia y evocación en el Románico hispano, 82-109. Aguilar de Campóo: Fundación Santa María la Real, 2016.

Castiñeiras González, Manuel A. “Un nuevo testimonio de la iconografía jacobea: Los relieves pintados de Santiago de Turégano (Segovia) y su relación con el altar 
mayor de la Catedral de Santiago". Ad Limina, 3 (2012), 73-117.

Cátedra, Pedro M. Liturgia, poesía y teatro en la Edad Media. Madrid: Gredos, 2005.

Cristóbal Antón, Luis. “Conservación y restauración de esculturas de madera". En Actas de los VIII cursos monográficos sobre patrimonio histórico, Reinosa, julio-agosto, 1997, editado por José Manuel Iglesias Gil, 193-208. Reinosa: Universidad de Cantabria-Ayuntamiento de Reinosa, 1998.

Daumet, Georges. "L'ordre castillan de l'Écharpe (Banda)". Bulletin Hispanique, 25 (1923), 5-32.

Donati, Piero. "Santa Lucia, 1450-1470 circa". En La Sacra Selva. Scultura lignea in Liguria tra XII e XVI secolo, editado por Franco Boggero y Piero Donati, 180-181. Ginebra-Milán: Skira, 2004.

Español, Francesca. "Los descendimientos hispanos". En La Deposizione lignea in Europa. L'immagine, il culto, la forma, 511-554. Perugia: Electa, 2004.

Exposición dirigida al Excmo. Sr. Ministro de Hacienda en nombre y de orden de S. M. la Reina por el intendente de su real casa y patrimonio, para probar así con los privilegios y escrituras de la fundación del monasterio de Santa María la Real de las Huelgas y el Hospital del rey, cerca de Burgos (...) que, siendo propios y patrimoniales de S. M. (...) no deben ser comprendidos en la ley de Desamortización. Madrid: Aguado Impresor de Cámara de S. M. y de su real casa, 1856.

Fernández-Ladreda Aguadé, Clara. “La imaginería en los monasterios cistercienses castellano-leoneses". En Monjes y monasterios. El Císter en el medievo de Castilla y León, dirigido por Isidro Bango Torviso, 411-426. Valladolid: Junta de Castilla y León, 1998.

Freedberg, David. El poder de las imágenes. Estudios sobre la historia y la teoría de la respuesta. Madrid: Cátedra, 1992.
García Avilés, Alejandro. “Imágenes ‘vivientes': Idolatría y herejia en las Cantigas de Alfonso X el Sabio". Goya, 321 (2007), 324342.

García Avilés, Alejandro. “'Este rey tenno que enos idolos cree': imágenes milagrosas en las Cantigas de Santa María". En Alfonso X El Sabio 1221-1284. Las Cantigas de Santa María, vol. II: Códice Rico, Ms.T-I-1 Real Biblioteca del Monasterio de San Lorenzo de El Escorial, Estudios, editado por Laura Fernández Fernández y Juan Carlos Ruiz Souza, 523-559. Madrid: Testimonio Compañía Editorial, 2011.

Gómez Redondo, Fernando. “El molinismo: un sistema de pensamiento letrado (12841350)". En Estudios de literatura medieval: 25 años de la Asociación Hispánica de Literatura Medieval, coordinado por Antonia Martínez Pérez y Ana Luisa Baquero Escudero, 45-81. Murcia: Universidad de Murcia, 2012.

González García, Miguel Ángel. “Representación de Santiago en la catedral de Ourense". Faro de Vigo, 27 de octubre de 2013.

Hernández Díaz, José. La Virgen de los Reyes, patrona de Sevilla y su archidiócesis. Estudio iconográfico (Sevilla: Imprenta Suárez, 1947), (reed. Sevilla: Guadalquivir, 1996).

Laguna Paúl, María Teresa. “La Virgen de los Reyes". En Maravillas de la España Medieval. Tesoro sagrado y monarquía, coordinado por Isidro G. Bango Torviso, vol. I, 435. Valladolid: Junta de Castilla y León, 2001.

Laguna Paúl, María Teresa. "Devociones reales e imagen pública en Sevilla". Anales de Historia del Arte, 23, n⿳丷. especial (II) (2013), 127-157.

Laguna Paúl, María Teresa. “Dibujos de la Virgen de los Reyes conservados en la colección Gestoso". Laboratorio de arte, 29 (2017), 617-634.

Linehan, Peter. "Ideología y liturgia en el reinado de Alfonso XI de Castilla". En 
Génesis medieval del estado moderno. Castilla y Navarra (1250-1370), 229-244. Valladolid: Ámbito, 1987.

Linehan, Peter. "The mechanics of monarchy: Knighting Castile's king. 1332". History Today, 43 (1993), 26-32.

Linehan, Peter. "Alfonso XI of Castile and the arm of Santiago (with a note on the Pope's foot)". En Miscellanea Domenico Maffei dicata. Historia Jus Studium, editado por Antonio García García y Peter Weimar, IV, 121-146. Goldbach: Keip, 1995.

Linehan, Peter. At the Edge of Reformation. Iberia before the Black Death. Oxford: Oxford University Press, 2019.

López Aydillo, Eugenio. Los cancioneros gallego-portugueses como fuentes históricas (con un glosario de voces del gallego arcaico). Nueva York-París: Revue Hispanique, 1923.

Lorenzo Arribas, Josemi. “La música en el monasterio de Las Huelgas en tiempos de su códice polifónico". En El códice de Las Huelgas, editado por Juan Carlos Asensio Palacios, 21-36. Madrid: Alpuerto, 2001.

Mariscal, Beatriz. "Historia y leyenda en el teatro de Lope de Vega, Las paces de los reyes y judía de Toledo". En Tiempo e historia en el teatro del Siglo de Oro, dirigido por Isabelle Rouane Soupault y Philippe Meunier, sin paginar. Aix-en-Provence: Presses Universitaires de Provence, 2015. https://books.openedition.org/pup/ 4706?lang=es

Martín, José Luis y Luis María Serrano Piedecasas. "Tratados de caballería. Desafíos, justas y torneos". Espacio, Tiempo y Forma (1991), 161-242.

Martínez Martínez, María José. “Las imágenes articuladas en las celebraciones áulicas: la escultura de Santiago del Espaldarazo de las Huelgas de Burgos". Codex aquilarensis, 30 (2014), 259-272.

Moralejo, Serafín. "Estatua sedente de Santiago coronado". En Santiago, camino de Europa. Culto y cultura en la peregrinación a
Compostela, 343. Santiago de Compostela: Xunta de Galicia, 1993.

Nieto Soria, José Manuel. Fundamentos ideológicos del poder real en Castilla (siglos XIII-XVI). Madrid: Eudema Universidad, 1988.

Nieto Soria, José Manuel. Ceremonias de la realeza. Propaganda y legitimación en la Castilla Trastámara. Madrid: Nerea, 1993.

Novoa y Varela, Miguel. Un recuerdo glorioso de las Huelgas de Burgos. Madrid: Tipografía de los Huérfanos, 1887.

Núñez de Castro, Alonso. Corónica de los señores Reyes de Castilla, Don Sancho el Deseado, Don Alonso el Octauo, y Don Enrique el Primero. En que se refiere todo lo sucedido en los Reynos de España, desde el año mil ciento y treinta y seis, hasta el de mil y docientos y diez y siete. Madrid: Pablo de Val, 1665.

Palacios Martín, Bonifacio. “Los símbolos de la soberanía en la Edad Media española. El símbolo de la espada". En VII Centenario del infante don Fernando de la Cerda, 1275-1975), 273-296. Madrid: Instituto de Estudios Manchegos, 1976.

Palacios Martín, Bonifacio. "Investidura de armas de los reyes españoles en los siglos XII y XIII". Gladius, vol. extraordinario Primer simposio internacional sobre las armas en la historia (1988), 153-192.

Payo Hernanz, René Jesús. El retablo en Burgos y su comarca durante los siglos XVII y XVIII. Burgos: Publicaciones de la Excma. Diputación de Burgos, 1997.

Payo Hernanz, René Jesús. El arte de la madera en Burgos durante los siglos XVII y XVIII. Burgos: Alcolea, 1997.

Pereda, Felipe. Las imágenes de la discordia. Política y poética de la imagen sagrada en la España del cuatrocientos. Madrid: Marcial Pons Historia, 2007.

Plötz, Robert. "Santiago Coronatio Peregrinorum". En Santiago, camino de Europa. Culto y cultura en la peregrinación a Com- 
postela, 344. Santiago de Compostela: Xunta de Galicia, 1993.

Porreño, Baltasar. Historia del Santo Rey don Alonso el Bueno. Alfonso VIII. Editado por Miguel Salas Parrilla. Cuenca: Diputación Provincial, 2018.

Porres Alonso, Bonifacio. Los trinitarios en Burgos. Historias de un convento (12071835). Córdoba: Secretariado trinitario, 2004.

Porro Girardi, Nelly R. La investidura de armas en Castilla. Del Rey Sabio a los Reyes Católicos. Valladolid: Junta de Castilla y León, 1998.

Ramos Vicent, María del Pilar. "Reafirmación del poder monárquico en Castilla: la coronación de Alfonso XI". Cuadernos de Historia medieval, 3 (1983), 5-36.

Rodríguez, Inmaculada. "Los reyes santos". En Visiones de la monarquía hispánica, editado por Víctor Mínguez, 133-170. Castellón de la Plana: Universitat Jaume I, 2007.

Rodríguez López, Amancio. El Real Monasterio de Las Huelgas de Burgos y el Hospital del Rey (Apuntes para su historia y colección diplomática con ellos relacionada). Burgos: Imprenta y Librería del Centro Católico, 1907.

Rodríguez Porto, Rosa María. “Mística regia y ambiciones compostelanas. La catedral de Santiago como espacio ceremonial para las monarquías castellana y portuguesa (1319-1332)". Codex aquilarensis, 30 (2014), 133-158.

Rodríguez Porto, Rosa María. “Knighted by the Apostle Himself. Political Fabrication and Chivalric Artefact in Compostela, 1332". En The Agency of Things in Medieval and Early Modern Art. Materials, Power and Manipulation, editado por Grazyna Jurkowlaniec, Ika Matyjaszkiewicz y Zuzanna Sarnecka, 51-60. Nueva YorkAbingdon: Routledge, 2018.

Rodríguez Velasco, Jesús. El debate sobre la caballería en el siglo XV. La tratadística ca- balleresca castellana en su marco europeo. Valladolid: Junta de Castilla y León, 1996.

Rosell, Cayetano, ed. Crónicas de los Reyes de Castilla. Madrid: Biblioteca de Autores Españoles-Ribadeneyra Editor, 1817-1883.

Ruiz, Teófilo. “Une royauté sans sacré: la monarchie castillaine du Bas Moyen Âge". Annales ESC, 39-3 (1984), 429-459.

Ruiz, Teófilo. "Images of Power in the Seals of the Castilian Monarchy: 1135-1469". En Estudios en homenaje a don Claudio Sánchez-Albornoz en sus 90 años, vol. IV, 455463. Buenos Aires: Fundación Claudio Sánchez Albornoz, 1986.

Sánchez-Albornoz, Claudio. "Un ceremonial inédito de coronación de los reyes de Castilla". Logos, 3 (1943), 75-97. Reeditado en Viejos y nuevos estudios sobre instituciones medievales españolas, vol. II, 1209-1236. Madrid: Espasa-Calpe, 1976-80.

Sánchez Ameijeiras, Rocío. "Santiago del Espaldarazo". En Santiago, camino de Europa. Culto y cultura en la peregrinación a Compostela, 420-421. Santiago de Compostela: Xunta de Galicia, 1993.

Sansterre, Jean-Marie. "La imagen activada por su prototipo celestial: milagros occidentales anteriores a mediados del siglo XIII". Codex Aquilarensis, 29 (2013), 77-98.

Saracho, Juan de y José Moreno Curiel. Jardín de flores de la gracia. Escuela de mejor doctrina, vida y virtudes de la prodigiosa $y$ venerable señora doña Antonia Jacinta de Navarra y de la Cueva, abadesa del Ilustríssimo y Real monasterio de las Huelgas, cerca de Burgos, del Orden del Glorioso y melifluo padre san Bernardo, sacada a la letra de los quadernos que, por mandado de sus confessores, dexó ella misma escritos. Burgos: Imprenta de Atanasio Figueroa, 1736.

Las siete partidas del rey don Alfonso el Sabio, cotejadas con varios códices antiguos por la Real Academia de la Historia. Madrid: Imprenta Real, 1807.

Torrón Durán, Francisco. “Imagen de Santiago del Espaldarazo de las Huelgas de 
Burgos". Abrente. Boletín de la Real Academia Gallega de Bellas Artes de Nuestra Señora del Rosario, 38-39 (2006-2007), 73-74.

Vauchez, André. “L'image vivante: quelques réflexions sur les fonctions des représentations iconographiques dans le domaine religieux en Occident aux derniers siècles du Moyen Âge". En Pauvres et riches. Société et culture du Moyen-Âge aux Temps Modernes. Mélanges offerts à Bronislaw Geremek à l'occasion de son sixantième anniversaire, 231-240. Varsovie: Wydawn. Naukone PWN, 1992. Reeditado en "Les images saintes: représentations iconographiques et manifestations du sacré". En André Vauchez. Saints, prophètes et visionnaires. Le pouvoir surnaturel au Moyen Âge, 79-91. París: Albin Michel, 1999.

Vanwijnsberghe, Dominique. "Réalité et fiction chez le Maître du Livre d'Heures de Dresde. Le frontispice du Cartulaire de l'Hôpital Saint-Jacques de Tournai (Tournai, Bibliothèque de la Ville, ms. 27)". En 'Als Ich Can'. Liber Amicorum in Memory of Professor Dr. Maurits Smeyers, editado por Bert Cardon, Jan Van der Stock y Domi- nique Vanwijnsberghe, II, 509-1546. Leuven: Peeters Publishers, 2002.

Virseda, Marta. “La Galería de los Reyes del Alcázar de Segovia: una revisión historiográfica". En Perspectivas actuales horizontes insólitos. Dinámicas y aportaciones teóricas en Historia del arte, editado por Helena Carvajal et al., 37-62. Logroño: Aguja de Palacio Ediciones, 2017.

Weaver, Elissa B. Convent Theatre in Early Modern Italy. Spiritual Fun and Learning for Women. Cambridge: Cambridge University Press, 2002.

Weaver, Elissa B. "Convent Education and the Role of Theater, 1500-1650". En Scritture, Carismi Instituzioni. Percorsi di vita religiosa in età moderna. Studi per Gabriella Zarri, editado por Concetta Bianca y Anna Scatigno, 499-512. Roma: Edizione di Storia e Letteratura, 2018.

Yarza Luaces, Joaquín. "Monasterio y Palacio del Rey". En Vestiduras ricas. El monasterio de Las Huelgas y su época 1170-1340, 15-34. Madrid: Patrimonio Nacional, 2005. 